NBER WORKING PAPER SERIES

\author{
TAXATION AND LABOR SUPPLY OF \\ MARRIED WOMEN: THE TAX \\ REFORM ACT OF 1986 AS A \\ NATURAL EXPERIMENT
}

\author{
Nada Eissa
}

Working Paper No. 5023

\author{
NATIONAL BUREAU OF ECONOMIC RESEARCH \\ 1050 Massachusetts Avenue \\ Cambridge, MA 02138 \\ February 1995
}

Comments welcome. I am grateful to seminar participants at Chicago, Harvard, Michigan, MIT, Northwestern, Princeton, UC Berkeley, UCLA, Yale and the Board of Governors for useful suggestions; to Richard Blundell, Gary Chamberlain, Susan Collins, Claudia Goldin, James Hines, Guido Imbens, Lawrence Katz, Jeffrey Liebman, Jonathan Skinner for comments; to Douglas Elmendorf and Martin Feldstein for helpful discussions and guidance; to Todd Sinai for providing the Fortran programs used with the NBER's TAXSIM model; and to the National Science Foundation for financial support provided during an earlier version of this paper. All errors are purely my own. This paper is part of NBER's research program in Public Economics. Any opinions expressed are those of the author and not those of the National Bureau of Economic Research.

(C) 1995 by Nada Eissa. All rights reserved. Short sections of text, not to exceed two paragraphs, may be quoted without explicit permission provided that full credit, including $\odot$ notice, is given to the source. 


\title{
TAXATION AND LABOR SUPPLY OF MARRIED WOMEN: THE TAX \\ REFORM ACT OF 1986 AS A \\ NATURAL EXPERIMENT
}

\begin{abstract}
This paper uses the Tax Reform Act of 1986 as a natural experiment to identify the labor supply responsiveness of married women to changes in the tax rate. The Tax Reform Act of 1986 reduced the top marginal tax rate by 44 percent (from 50 percent to 28 percent), but changed less the marginal tax rate for those further down the income distribution. I analyze the response of married women at or above the 99th percentile of the income distribution, using as a control group women from the 75th percentile of the income distribution. I therefore identify the tax effect as the difference between the change in labor supply of women with large tax rate reductions and the change in labor supply of women with small tax rate reductions.

I find evidence that the labor supply of high-income, married women increased due to the Tax Reform Act of 1986. The increase in total labor supply of married women at the top of the income distribution (relative to married women at the 75 th percentile of the income distribution) implies an elasticity with respect to the after-tax wage of approximately 0.8 . At least half of this elasticity is due to labor force participation. Use of a second control group supports the participation response but is inconclusive on the hours of work response.
\end{abstract}

\author{
Nada Eissa \\ Department of Economics \\ University of California, Berkeley \\ Berkeley, CA 94720 \\ and NBER
}




\section{Introduction}

The impact of taxation on labor supply incentives has been a subject of intense interest to public finance economists for quite some time. The large empirical literature, however, has failed to generate any consensus on the parameter of interest: the elasticity of labor supply with respect to the after-tax wage. In fact, for married women, estimates of this elasticity suggest that we may expect anywhere from a 3.2 percent increase to a 37 percent decrease in labor supply in response to the 16 percent increase in the top marginal tax rate by the Omnibus Budget and Reconciliation Act of $1993 .{ }^{1}$

The existing literature on taxation and labor supply suffers from three major problems. First, the marginal tax rate faced by an individual is endogenous to the chosen amount of labor supply. Second, the wage itself is endogenous: individuals who earn a higher wage may have stronger preferences for work caters paribus than individuals who earn a lower wage. These unobservables would generate a positive correlation between the wage and the error term in a labor supply equation, and as a consequence bias the wage coefficient. Third, the estimated tax effect is sensitive to the functional form chosen for the regression because the marginal tax rate is a nonlinear function of the very determinants of labor supply behavior (income and family size). Since the true regression function is unknown, the estimated coefficient on the net wage may reflect underlying tastes for labor supply, rather than the impact of taxes.

These objections suggest that an alternative means of estimating labor supply responsiveness is to find exogenous time variation in marginal tax rates, such as that provided by policy changes. The two major tax reforms of the 1980's, the Economic Recovery Tax Act of 1981 and the Tax Reform Act of 1986, provide an opportunity for such an analysis. In 1980, the marginal tax rate on individuals earning the highest income was 70 percent; by 1988 , that rate had fallen to 28 percent (a total reduction of 60 percent). No studies have used the major tax reductions of the 1980's to identify labor supply responsiveness to tax changes. Burtless (1991) and Bosworth and Burtless (1992) examine long-term trends in labor supply over this period, but do not attempt to estimate a labor supply elasticity.

This paper uses the Tax Reform Act of 1986 (TRA86) as a natural experiment to identify the responsiveness of married women's labor supply to changes in the tax rate. I analyze the work behavior of married women at or above the $99^{\text {th }}$ percentile of the income distribution. Two factors guide this choice. First, this group is most likely to have been significantly affected by the tax reforms. TRA86

\footnotetext{
${ }^{1}$ See Hausman (1985) for a review of the tax and labor supply literature.
} 
lowered marginal rates for upper income individuals much more than for those further down the income distribution. Individuals earning 100,000 dollars (1985\$) had their marginal rates lowered from 45 to 33 percent, whereas those earning 40,000 dollars had no change in their marginal rate of 28 percent. Second, married women are widely believed to be more responsive to a given change in the tax rate than other demographic groups.

Estimating the behavioral response of married women to this tax reform is complicated by two factors. First, there is an underlying trend in women's labor supply over the past two decades. In 1970, the labor force participation rate of married women was 41 percent; by 1989 it had reached 58 percent. Second, shocks to labor demand during the period of the reform may also have affected labor force participation rates and hours of work. It is well established that the demand for more educated workers rose sharply in the 1980's (Katz and Murphy, 1992). To control for both the secular trend in labor supply and for any contemporaneous shocks to labor demand, I use a control group of women who faced much smaller tax reductions due to TRA86. These women are at the $75^{\text {th }}$ percentile of the income distribution. Thus, I identify the impact of the tax reform as the difference between the change in labor supply of women with large tax rate reductions (treatment group) and the change in labor supply of women with small tax rate reductions (control group). This differences-in-differences approach allows me to estimate a labor supply elasticity without explicitly parameterizing the tax system, and therefore without relying on functional form assumptions for identification.

The identification condition is that there is no contemporaneous shock to the relative labor market outcomes of the treatment and control groups. This condition is somewhat tenuous because the treatment and the control groups differ in observable characteristics. I therefore pursue three strategies for testing the robustness of my basic results. First, I use a second control group from the $90^{\text {th }}$ percentile of the same income distribution. Second, because treatment group women are more educated than control group women, I examine whether the response in labor supply may be explained by changes in the relative returns to education. Finally, I test whether the treatment and control groups had different trends prior to 1986 .

I find evidence that the labor supply of high-income, married women increased due to the Tax Reform Act of 1986. The increase in total labor supply of married women at the top of the income distribution (relative to married women at the $75^{\text {th }}$ percentile of the income distribution) implies an 
elasticity of with respect to the after-tax wage of approximately 0.8 , consistent with previous results based on cross sectional data (Hausman 1981, Triest 1990). The composition of this labor supply elasticity has been a major issue in the literature: it is generally believed that the participation decision is far more elastic to changes in taxes than are hours of work for employed women (Mroz 1987, Triest 1990, Heckman 1993). For high-income women, my results suggest that at least half of the responsiveness is on the participation margin. The increase in labor force participation of high-income women relative to those at the $75^{\text {th }}$ percentile of the income distribution implies an elasticity of approximately 0.4 . The $90^{\text {th }}$ percentile control group provides support for the participation response but is inconclusive on the hours of work response. These results are robust to various specification tests.

The paper proceeds as follows: Section I briefly reviews the empirical literature on taxation on labor supply. Section II describes changes in the tax treatment of labor income due to the Tax Reform Act of 1986. Section III presents the identification strategy. Section IV describes the data and presents the raw differences-in-differences results. Section V presents the regression framework and specification, and Section VI presents the regression results. Section VII discusses policy implications and concludes.

\section{Literature}

The literature on the impact of taxation on labor supply is extensive. The traditional approach, followed in both the labor and public finance fields, was to posit a linear budget constraint and estimate a structural labor supply equation. Generally, ordinary least squares and two-stage least squares were used. Hausman's (1985) survey of the literature on taxes and labor supply identifies the range of estimates of the uncompensated net-wage elasticity for married women at -0.2 to 2.3 .

Most of the studies that Hausman surveys do not account for the nonlinearities in the budget constraint created by the progressivity of the tax system. These nonlinearities were the starting point for the influential work of Hausman. Hausman (1981) uses maximum likelihood methods to estimate a structural labor supply equation under the assumption of a nonlinear budget set. Using cross-sectional data from the 1975 Panel Study of Income Dynamics (PSID), he estimates a net-wage elasticity of approximately 1 for married women.

Various studies have applied this methodology to different data for the United States and to data 
for different countries (see the papers in the Journal of Human Resources, 1990). For example, Triest (1990) uses the 1984 PSID data to estimate a labor supply elasticity of 1.1 for married women. For employed women, Triest estimates an elasticity of 0.2 for hours of work. Triest's results suggest that the participation decision is more responsive to changes in the net-wage than are hours conditional on working. Mroz (1987) finds similar results in his sensitivity analysis of married women's labor supply. These findings support Hausman and Poterba's (1987) prediction that the impact of TRA86 would be in the labor force participation of secondary earners.

Nonlinear budget set estimates have been shown to be sensitive to small changes in specification. In order to generate a well defined statistical model, the Slutsky condition is imposed at kink points on the budget constraint; this amounts to constraining the income effect to be negative (MaCurdy et al. 1990). In their analysis of the labor supply of prime age males, MaCurdy et al. estimate an unconstrained model and find that this condition is violated. Blundell et al.(1993) relax some of these assumptions in the case of married women in the United Kingdom.

More generally, the literature has been criticized along various lines. First, the tax rate is endogenous to the hours of work chosen. For married women, this problem is attenuated by instrumenting for the marginal tax rate with the first hour marginal tax rate. The model of labor supply assumed is that the woman conditions her labor supply on her spouse's hours of work. Therefore her first hour marginal rate is her spouse's last hour rate, and is exogenous to her labor supply behavior. Second, the tax coefficient is dependent on the functional form chosen for the regression. The marginal rate faced by a taxpayer is a nonlinear function of both income and family size. Because the "true" specification of the labor supply equation is unknown, any underlying tastes for work that are correlated with income or family size may be reflected in the tax coefficient (Feenberg 1987). Interpreting the tax price coefficient with any degree of confidence therefore requires that all individual variation correlated with these variables be removed. Third, the wage itself is endogenous. Preferences for work may be correlated with the wage rate, so that even controlling for observable characteristics, women who like to work are paid a higher wage than those with weaker preferences for work. In this case, the estimated wage coefficient reflects, partially, unobserved tastes for work. ${ }^{2}{ }^{3} \mathrm{~A}$ more promising approach to

\footnotetext{
${ }^{2}$ Efforts to address this endogeneity with instrumental variables have generated estimates sensitive to the set of instruments used. In addition, there is substantial measurement error in the wage which is negatively correlated
} 
estimating labor supply responsiveness therefore is to find exogenous time variation in marginal tax rates, such as that provided by policy reforms.

A few studies have analyzed the impact of changes in tax laws on individual behavior. One set of studies focuses primarily on the revenue effects of the Economic Recovery Tax Act of 1981 (Lindsey $1987,1988,1990$ ). Lindsey (1987) uses tax return data from 1979 and 1982-1984 to analyze the impact of the tax reductions on pre-tax income at various points along the income distribution. He imputes a post-ERTA income distribution based on the pre-ERTA tax code, and compares it to the actual income distribution after the tax reform. Lindsey finds a significant increase in income at the upper end of the distribution. This finding sheds little light on the responsiveness of labor supply, however. As Lindsey (1987) notes, "the response of income is not the same as the response of labor supply... [It] includes, but is by no means limited to [labor supply responses]." More specifically, the increase in income may be due to changes in reporting practices, rather than to changes in work behavior. Because the top marginal rate on unearned income fell from 70 percent to 50 percent during this period, individuals had a fewer incentives to channel their investments into untaxed areas and as a result report more as taxable income. ${ }^{4}$

The only studies that directly examine the labor supply effects of tax reforms in the 1980's are Burtless (1991) and Bosworth and Burtless (BB, 1992). These studies analyze the trend in labor supply for different demographic groups using Current Population Survey data from 1968 to 1988, and from 1968 to 1990 respectively. Both studies estimate aggregate time series labor supply equations, and find a significant break in the labor supply trend of married women starting in 1981 , which they attribute to the Economic Recovery and Tax Act of 1981. Burtless (1991) finds evidence that the impact of the tax reforms is on hours of work, rather than labor force participation. His results are sensitive to the

with hours of work (Mroz 1987).

${ }^{3}$ Moreover, because a significant portion of married women are nonparticipants, wages must be imputed for them. Selection models used to impute wages have been criticized for their dependence on functional form assumptions for identification as well.

${ }^{4}$ The response may have been due as well to changes in compensation decisions. The Tax Reform Act of 1969 provided a tax credit for individuals whose earned income placed them above the 50 percent bracket (in 1980, this affected individuals with taxable income over $\$ 60,000$ (1980 dollars)). The credit was based only on earned income: a taxpayer with earned income below the 50 percent bracket, and capital income which places him above the 50 percent bracket would receive no credit. Therefore, the adjustment rarely capped the marginal rate at 50 percent, especially if the taxpayers' share of capital income in total income was large. In fact, Lindsey (1981) shows that a majority of taxpayers eligible for the maximum tax faced marginal rates in excess of 50 percent. 
specification used, however. Extrapolating to 1989, BB find the largest responses for bottom quintile and top quintile older women. For the latter group, they estimate an increase of 27 percent in annual hours of work between 1981 and 1989, and argue: "It is likely that part of the estimated change among highincome women is attributable to marginal tax rate reductions." There are two major problems with this analysis, however. First, BB use total family income to rank individuals: ceteris paribus, this allocates women who are high earners to the top quintile group. Over time, their strategy selects women who are increasing their labor supply and biases upwards their estimated response. Second, it is widely documented that the skill premium rose dramatically in the 1980s (Katz and Murphy 1992, Murphy and Welch 1992). As BB note, the labor supply of top quintile women may have increased due to higher wages. ${ }^{5}$ The changing returns to education is a concern with my identification strategy as well; however, I address it partially by controlling for individual characteristics. Finally, the aggregate nature of their analysis does not allow them to estimate a labor supply elasticity with respect to the net wage.

The strategy I follow allows me to estimate the behavioral parameter of interest, the elasticity of labor supply. In addition, I avoid the identification problems faced in the cross sectional analysis of taxes and labor supply. Stated differently, I am able to estimate a policy parameter without relying on functional form assumptions for identification. Before discussing the methodology used in this paper, however, I review the features of the Tax Reform Act of 1986 that are relevant for labor supply.

\section{The Tax Reform Act of 1986}

Prior to 1986, the U.S. personal income tax schedule consisted of fourteen brackets, ranging from 11 percent to 50 percent. The highest tax rate of 50 percent applied to married couples filing jointly, with taxable income over $\$ 170,000 .^{6}$ The basic federal schedule (for a married couple filing jointly) is shown in Figure I. This tax schedule does not include social security taxes $(7.15$ percent on the

\footnotetext{
${ }^{5}$ The puzzle of why labor supply increased dramatically for those at the bottom of the distribution remains, since they are likely to be unskilled. I will examine this pattern in future work with particular reference to the Earned Income Tax Credit.

${ }^{6}$ All figures are in 1985 dollars (deflated by the CPI) and are taken from Pechman (1987).
} 
employee's side), or state and local income taxes. ${ }^{3}$ Some upper-income married women faced a marginal rate on the first hour of work as high as 70 percent. Starting in 1981 , secondary earners were allowed a deduction of 10 percent of earnings, up to a total of $\$ 3000 .^{8}$ As shown in Figure $I$, this would lower the tax schedule proportionally by 10 percent for women earning under $\$ 30,000$.

The Tax Reform Act of 1986 shifted the personal income tax system toward a flat rate schedule imposed on a broader tax base. The tax schedule was collapsed, nominally, to two brackets, 15 percent and 28 percent. The phasing out of the 15 percent bracket and of the personal exemption at higher incomes created a 33 percent bracket for those whose taxable earnings are between $\$ 65,400$ and $\$ 136,000$ (for married couples filing jointly). In addition, the personal exemption was doubled, and indexed for inflation starting in 1990. Figure I also presents the tax schedule for 1989 . There is one immediate observation. Individuals at the top of the income distribution experienced the largest reductions in marginal tax rates. The top marginal tax rate on income was lowered from 50 percent to 28 percent. More generally, individuals with taxable incomes in excess of $\$ 100,000$ experienced a reduction in statutory marginal rates in excess of 30 percent.

In addition, the secondary earner tax deduction was repealed. The repeal of this provision is not likely to be important for the analysis, however. The reduction in marginal rates after 1986 implies that the value of the deduction in 1989 would have been much lower even if marginal rates had not been reduced. For a working woman at the top of the income distribution (by virtue of her husband's wage income and any family asset income) but earning under $\$ 30,000$ herself, this suggests a reduction in the marginal rate of 17 percentage points (from 45 percent to 28 percent), rather than 20 percentage points (from 45 percent to 25 percent) if the deduction had not been repealed.

Within the framework of lower marginal tax rates, the reforms were required to meet two goals: distributional and revenue neutrality. These requirements meant that the sharp reduction in marginal rates

\footnotetext{
${ }^{7}$ The social security tax is a payroll tax and therefore would apply even to women in the top tax bracket whose earnings fall below the maximum taxable income level. The social security (OASI) tax rate, which should be applied, is defined as the difference between the present value of lifetime social security payments and social security benefits. Because married women often receive benefits as dependents rather than as workers, they face the full, 10.4 percent, statutory rate (Feldstein and Samwick, 1992). I assign the statutory employee's share mainly for convenience.

${ }^{8}$ ERTA also reduced marginal tax rates by 23 percent within each tax bracket. Prior to 1981 , the top marginal tax rate on the secondary earner in the household could have been as high as 90 percent.
} 
for the high-income group had to be balanced by an increase in the share of their income subject to taxation. ${ }^{9}$ In pursuit of this goal, TRA86 removed from the tax code the 60 percent capital gains exclusion, some deductions for interest expenses, deductions on Individual Retirement Account contributions, passive losses and other provisions relevant for those at the top of the income distribution. These changes reduce the income effect of the tax reform for individuals at the top of the income distribution.

\section{Identification Strategy}

I explore the effect of the Tax Reform Act of 1986 on the labor supply decisions of high-income, married women. This choice is predicated on two factors. First, the responsiveness of married women to a given change in the net wage is believed to be large relative to other demographic groups (single men, married men, and female heads of households). If a response is to be found, it is most likely to be among married women.

Second, the Tax Reform Act of 1986 affected an identifiable group of women significantly more than others. Hausman and Poterba (1987) note that the new law has a dramatic effect on individuals with very high incomes and with very low incomes, but little impact on most other individuals. ${ }^{10}$ They estimate that 40 percent of the tax-paying population faces either the same or higher rates following the reforms as before, and only 11 percent face marginal tax rates that are lower by 10 percentage points or more. After TRA86, a woman in the top tax bracket earning under $\$ 30,000$ in wages would have seen a 36 percent increase in her after-tax wage. ${ }^{11}$ Again, labor supply responses will be seen most clearly among high-income women.

\footnotetext{
9 The revenue shortfall from personal income tax reductions were to be made up in part by increases in the corporate income tax.

${ }^{10}$ I do not study those at the bottom of the income distribution. For the most part, the impact on the poor is inframarginal, i.e., average rather than marginal tax rates were lowered. In addition, approximately 6 million people at the bottom of the income distribution were removed form the tax rolls due to an increase in the standard deduction (Bosworth and Burtless, 1992).

"If her annual earnings are above $\$ 30,000$, the increase in the after tax wage is 50 percent. Both calculations include the social security payroll tax.
} 
If the labor supply function of married women were stable over time, and if one were sure that there were no contemporaneous shocks to labor market outcomes over the period, one could identify the effect of taxes by comparing the post-1986 and pre-1986 hours of the affected group. However, labor supply by married women has been increasing significantly over time (Burtless 1991). The problem this introduces is that we need a counterfactual to determine the impact of taxes; that is, what would the change in hours have been had there been no change in marginal tax rates? The difference between this and the actual change in hours worked would then be the impact of TRA86.

One approach to solve this problem is to generate a comparable group of married women with similar labor market trends who did not face the same "treatment." The treatment here is somewhat difficult to define because many women faced some reduction in taxes. I define the treatment to be a tax cut of at least 10 percentage points. One can then compare the change in hours of the treatment and of the control group over the period as a means of deducing the tax effect. This, of course, is the standard differences-in-differences approach. This strategy attempts to remove any extraneous factors influencing the supply of labor by married women correlated with, but independent of, the tax reforms. Conceptually, one can see this in the following box, in which average annual hours worked by each group before and after the tax reform are presented.

\begin{tabular}{|c||c|c|}
\hline & $\begin{array}{c}\text { Before } \\
\text { TRA86 }\end{array}$ & $\begin{array}{c}\text { After } \\
\text { TRA86 }\end{array}$ \\
\hline \hline $\begin{array}{c}\text { Large Tax Rate Reduction } \\
\text { "Treatment Group" }\end{array}$ & $\mathrm{H}_{\mathrm{tb}}$ & $\mathrm{H}_{\mathrm{ta}}$ \\
\hline $\begin{array}{c}\text { Small Tax Rate Reduction } \\
\text { "Control Group" }\end{array}$ & $\mathrm{H}_{\mathrm{cb}}$ & $\mathrm{H}_{\mathrm{ca}}$ \\
\hline
\end{tabular}

The change in hours worked by high-income women is $\left(\mathrm{H}_{\mathrm{ta}}-\mathrm{H}_{\mathrm{tb}}\right)$. Part of this change will be due to reductions in the marginal tax rate, and part will be due to extraneous factors such as changes in labor demand or in social norms. The assumption is that these non-tax factors will be reflected in the change in hours worked by women who experience small tax rate reductions, given by $\left(\mathrm{H}_{\mathrm{ca}}-\mathrm{H}_{\mathrm{cb}}\right)$. The test that TRA86 increased labor supply is a test that

$$
\left(\mathrm{H}_{\mathrm{ta}}-\mathrm{H}_{\mathrm{tb}}\right)-\left(\mathrm{H}_{\mathrm{ca}}-\mathrm{H}_{\mathrm{cb}}\right)>0 \text {. }
$$

In other words, I test whether women who faced significant tax reductions increased hours more than 
women with smaller tax reductions.

The difference between the outcomes of the treatment group and what these outcomes would have been in the absence of treatment is defined as the effect of the tax reductions. The latent variable 'labor supply of high-income women post 1986 in the absence of the tax reforms' is imputed as the sum of their labor supply before the tax reforms and the increase in labor supply of 'small tax rate reduction' women over the period. Therefore, the effect of the tax reductions is the difference between actual labor supply for high-income women post 1986 and the latent variable as derived from the control group.

Because the tax reforms occurred at the federal level, all women within an income group were affected equally. ${ }^{12}$ Therefore, the variation in marginal tax changes occurred across the income distribution. This suggests that any group which could control for contemporaneous shocks to labor supply must come from different points along the income distribution. ${ }^{13}$

The choice of groups based on income immediately introduces an endogeneity problem. If total family income were used, then the assignment of women to each of the two groups becomes endogenous to the earnings of the wife. Ceteris paribus, women in the treatment group would be high earners relative to women in the control group. The changes in tax rates are then endogenous to the wife's earnings: women who either earn a higher wage or work more hours will face larger tax reductions than women who either earn a lower wage or work fewer hours. Choosing women who are high earners after 1986 selects those who have responded to the tax changes; this would bias upward the estimated response and labor supply elasticity of the treatment group. To remove this bias, the choice of the treatment and control groups is based on other household income -- the sum of the husband's labor income and any nonlabor income received by the family. I assume, therefore, that the wife conditions her participation and hours decision on her spouse's labor supply decision. This secondary earner model has been used widely in the literature. It is particularly convenient in the context of taxation analysis since it generates the first

\footnotetext{
${ }^{12}$ Of course the treatment of federal taxes at the state level will generate some differences.

${ }^{13}$ Conceptually, an alternative is to use the differences in state tax systems to construct a better control group. Three states (Vermont, Rhode Island and Nebraska) base their state tax liabilities on the federal tax liability. Therefore reductions in federal marginal tax rates at the top of the distribution generate significant reductions in the state marginal tax rates (top bracket women in Vermont, for example, had a 6 percentage point reduction in the state marginal rate due to TRA86). As a means of identifying the tax effect, one could then compare the change in hours for women in such states to women at the same point in the income distribution residing in states where state marginal rates did not change. The problem here is that sample sizes are likely to be too small.
} 
hour marginal tax rate faced by the wife as her spouse's last hour marginal rate.

The secondary earner model implies that using other household income to allocate women to the treatment and control group is exogenous to the labor supply decisions of the wife. The more important aspect of this assumption is clearly that the husband's earnings are exogenous to the wife's labor supply. The evidence on this model is inconclusive: Mroz's (1987) results suggest that other household income is exogenous to the labor supply of the wife, while Hausman and Ruud (HR, 1984) fail to reject a joint household model of labor supply.

If labor supply decisions are made at the household level instead, my estimates would be biased. The direction of the bias will depend on the model of household behavior assumed. If the household maximizes a family utility function (defined over the leisure times of both husband and wife) then the bias depends on the sign of cross-substitution effect: the change in the wife' hours of work due to a compensated change in the husband's wage rate. That parameter depends in turn on whether leisure times by the wife and the husband are substitutes or complements: if they are complements (substitutes), the cross substitution effect is positive (negative) and the bias is upwards (downwards). Evidence on the sign of the cross-substitution effect is inconclusive: Horney and McElroy (1980) find negative cross effects while Heckman (1971) finds positive cross effects (see McElroy 1981). In bargaining models of household labor supply, family members maximize utility (defined over own leisure) subject a family budget constraint. In this case, changes in the husband's earnings would affect the wife's labor supply only through an indirect income effect. My estimates would be biased towards zero. Of course, if the husband's own hours of work are insensitive to changes in the wage, the bias will be small regardless of the model of labor supply assumed. ${ }^{14}$

I choose the control group in the following manner. First, these women must be at a point in the income distribution far enough from the high-income group that their marginal tax rate does not fall by as much. Second, they cannot be so far down the income distribution that they differ fundamentally from the treatment group in terms of the labor demand and non-tax related labor supply shocks they face over the period. Because marginal tax rates changed for the majority of women, an implicit assumption of this framework is that women in the control group have the same elasticity to a given tax change as

\footnotetext{
${ }^{14}$ HR's own-wage elasticity estimates are smaller than, but similar in magnitude to estimates derived from the basic model.
} 
high-income women. ${ }^{15}$ The conjecture then is that the more distant these groups are from each other along the income distribution, the less likely it is that this assumption holds. The group I choose is women who are at the $75^{\text {th }}$ percentile of the income distribution.

The concern which arises at this point is that the control and the treatment groups may differ in either observable or unobservable characteristics, or both. That is, conditional on other household income, the allocation of the treatment and the control group may be non-random. Differences in the labor market outcomes of high and $75^{\text {th }}$ percentile-income women may therefore reflect either a treatment effect or a lack of comparability of the two groups. Any bias due to differences in observable characteristics will be reduced in a regression framework by controlling for the relevant factors. There remains the concern that the treatment and the control groups differ in unobserved attributes. If the proposition is that women in the treatment group are more 'motivated' than women in the control group, we would need to establish that more motivated women respond to a change in the tax rate in different ways than do less motivated women. That is, this strategy will generate unbiased results unless there is a correlation between characteristics of high-income men and their spouses' labor supply preferences and this correlation either changes over the period of interest or it is relevant for labor supply responsiveness to taxes. ${ }^{16}$ The hypothesis of no bias in the estimated labor market outcomes of the high-income and $75^{\text {th }}$ percentile women is of course not testable with only one control group. Therefore, I choose a second control group, closer to the treatment group in terms of observable characteristics, from the $90^{\text {th }}$ percentile of the same income distribution. ${ }^{17}$ This second group provides a test of the assumption that controlling

${ }^{15}$ This is perhaps the most troublesome assumption in the paper. Unfortunately, there is no evidence in the literature concerning differences in elasticities across income classes because essentially all of the empirical work is based on cross-sectional data.

${ }^{16}$ This issue may be restated in a different way. If individuals marry those that are like them (i.e., there is positive assortative mating), then women in the treatment group will have different characteristics than women in the control group. To the extent that these differences are observable, the resulting biases can be removed by controlling for the relevant factors. The potential problem arises if there is positive assortative mating in terms of unobservable traits: for example, if high income men are more "intelligent" than low income men, and "intelligent" men are more likely to mate with "motivated" women. If education is a signal of these traits, then evidence suggests that there is positive assortative mating: the correlation in the 1989 CPS between education of married men and their spouses' is 0.65 . This correlation generates a bias in my estimation only to the extent that one can plausibly argue that more "motivated" women have different responses to taxes than do less motivated women.

${ }^{17}$ To the extent that unobservables are correlated with income as well, the $90^{\text {th }}$ percentile group should be a better control group. 
for observed characteristics suffices to estimate the treatment effect. Finding similar results for upperincome women when either $75^{\text {th }}$ or $90^{\text {th }}$ percentile income women are used as a control group, and no effect for the $90^{\text {th }}$ percentile using the $75^{\text {th }}$ as a control group, increases confidence in the identification strategy. ${ }^{18}$

The identifying assumption needed is that there be no contemporaneous shock to the relative labor market outcomes over the period of the tax reforms. This includes both no relative demand and no relative supply shocks. This identification condition is particularly tenuous in this experiment since the groups differ in important demographic characteristics. High-income women tend to be older and more educated than their counterparts further down the distribution. These differences suggest that high-income women may be employed in different types of jobs than women from further down the income distribution, and consequently may face different shocks to labor demand. An increase in labor demand for upper-income women between 1985 and 1989 would lead to an increase in the hours of these women relative to the hours of women in the control group independently of the marginal tax rate reductions. Note that a similar argument would hold for relative shifts in the labor supply function. If preferences for work by high-income women strengthened over the period, then one would observe an increase in their relative supply of labor independent of the tax reforms. In this framework, the effects of these shocks would be attributed to tax changes, with the result being an artificially large estimated elasticity of labor supply.

I test for shocks to relative labor market outcomes in the following way. Education is clearly the most natural channel through which labor demand shocks operate. This intuition suggests a second test of the identification condition: allow the impact of education on labor market outcomes to vary over the period of the reforms. To the extent that part of the increase in hours of work is due to greater demand for more educated women, this test will generate a more precise measure of the tax effect.

Implicit in this analysis is the condition that in the absence of changes in the marginal tax rates no significant differences exist in the relative pattern of labor supply, i.e. $\left(\mathrm{H}_{\mathrm{ta}}-\mathrm{H}_{\mathrm{tb}}\right)-\left(\mathrm{H}_{\mathrm{ca}}-\mathrm{H}_{\mathrm{cb}}\right)$ should be zero. While this condition is not testable for the period of interest, it is possible to test for in a period during which no major tax reforms occurred. This generates yet a third test of the identification assumption. I analyze the relationship between the treatment and the control groups in a period previous

\footnotetext{
${ }^{18}$ Rosenbaum (1987) discusses the necessary conditions for this test to be valid.
} 
to the policy reforms of 1986 , when relative marginal tax rates remained fairly constant. If the control groups are valid, it should be the case that there is no significant estimated difference in relative hours over the period.

The discussion thus far has assumed that the tax reductions would increase labor supply by high income women. Basic microeconomic theory predicts that reductions in tax rates affect labor supply through income and substitution effects, which work in opposite directions. The substitution effect leads to an increase in labor supply, while the income effect leads to greater consumption of leisure. This analysis implicitly assumes that individuals are employed when taxes are reduced. Taxes will affect the participation decision, however, only through a substitution effect. For individuals who are not working, there will be no income effect of a tax reduction because hours of work, and therefore labor income, are zero. Thus a reduction in taxes cannot reduce labor force participation. For married women, the analysis is more complicated since the spouse will be earning labor income, which presumably will be affected by uncompensated tax changes. The Tax Reform Act of 1986 generated largely compensated changes in taxes on average within each income class since the tax base was expanded at the same time tax rates were reduced. Therefore, it should still be the case that mainly the substitution effect operates on the participation margin for married women.

\section{Data}

\section{IV.1 Sample}

I use data from the March Current Population Survey (CPS) from 1984 to 1986, and from 1990 to 1992. The March CPS data come from the March Annual Demographic Supplement, a survey of approximately 57,000 households. They provide annual labor market and income information for the year previous to the March survey, so income and labor supply data are actually for 1983 to 1985 and 1989 to $1991 .{ }^{19}$ Because TRA86 was not fully implemented until 1988, I begin the post-1986 period in the first year after the changes in marginal tax rates were fully phased in.

${ }^{19}$ Demographic information is recorded for the survey year, however. A woman who was single in 1989 but married into a high-income household in 1990 would enter the sample in 1990 as a high-income woman. The labor market information I attribute to her is for 1989. Although TRA86 reduced the marriage tax (and altered marriage incentives), it is unlikely that this feature of the CPS will matter for the results. 
The grouping of data from three years prior to 1986 and three years after 1986 is based on sample size considerations which will become clear as I describe the choice of the two groups. The sample is made up of married women between the ages of 20 and 64 who were, at the time of the interview, residing with their spouses. I exclude women who were self-employed (both incorporated and unincorporated), ill or disabled, and whose husbands are unemployed during the year previous to the survey. ${ }^{20}$ In addition, the sample is restricted to women for whom there is no missing information.

The CPS provides information on individuals, families, and households. The relevant unit of analysis for this study is a tax-filing unit, however. I define the tax-filing unit to include the husband, wife, and children under the age of $18 .^{21}$ The income distribution used to select the treatment and the control groups is constructed as the difference between the total income of the tax-filing unit and the wife's wage and salary income.

The treatment group is made up of married women at or above the $99^{\text {th }}$ percentile of their CPS income distribution in all years. There are 1474 women in this group. These women are generally in families which earn in excess of $\$ 90,000$ per year, with average taxable income in excess of $\$ 70,000$. Expanding the high-income group to include women from further down the income distribution runs the risk of introducing women whose taxes did not change by as much.

The first control group includes women between the $75^{\text {th }}$ and the $80^{\text {th }}$ percentiles of the same income distribution. These women are in families with average total income of $\$ 47,100$ and average "other household income" of $\$ 37,900$. Summary statistics for the groups are in Table I. Women in the control group are younger (40.6 vs. 47.6 years), less educated (13.3 vs. 14.8 years of schooling), and work more than their counterparts higher in the income distribution (1092 vs 696 hours). ${ }^{22}$

As stated earlier, a comparison of these two groups will not by itself provide a convincing test of the hypothesis. Therefore I choose a second control group between the $90^{\text {th }}$ and the $95^{\text {th }}$ percentiles.

\footnotetext{
${ }^{20}$ I do not restrict husbands to be full-time workers. At the chosen points along the income distribution, however, most husbands are working full time.

${ }^{21}$ Income earned by children is excluded from that of the tax-filing unit.

${ }^{22}$ These averages exclude women in 1992, since the CPS changed its coding of the education variable starting in 1992. Previously an individual's exact years of schooling were reported. Currently the education variable has more detail on the type of degree attained but certain years of schooling are bracketed (for example, 5-7 and 15-18 years). It is unlikely that these averages differ for the 1992 sample.
} 
Because these women are closer to the 'treatment' group than are $75^{\text {th }}$ percentile women, there is less potential for extraneous shocks which may confound the results. Summary statistics for this group are also on Table 1. Similar comparisons hold for this group, but the differences are less extreme. These women are close enough to the treatment group, however, that they are more likely to have their "own" effect of TRA86 than are women in the $75^{\text {th }}$ percentile group.

Marginal tax rates are calculated by the National Bureau of Economic Research tax simulation model (TAXSIM). I use information on family wage, dividend, interest, farm, self employment, and social security income to calculate the marginal tax rate faced by each woman. In addition I assume that all married couples file jointly, and that all itemize their deductions. I assign each woman the average itemized deduction for her income class (from the Statistics of Income data). I then calculate the federal marginal tax rate for wage and salary income. Women earning under $\$ 30,000$ (nominal) in any given year before 1986 are given a 10 percent reduction in the marginal tax rate, due to the secondary earner tax deduction. In addition, those whose earnings fall below the social security maximum taxable earnings are assigned the employee's share of the FICA payroll tax. Figure II presents the approximate location of each group on the statutory federal tax schedule; it clearly highlights the differences in the tax rate reductions among the treatment and control groups. This figure shows the tradeoffs in using the $75^{\text {th }}$ vs the $90^{\text {th }}$ percentile control group: while the latter is a better control group in that it is more similar to the treatment group in observable characteristics, it generates a less clean experiment because its tax rate changes were not small.

\section{IV.2 Basic Differences-in-Differences Results}

I now consider the impact of TRA86 on the marginal tax rates and labor supply of each group of women. The first set of results I discuss are of marginal tax rate changes. Table IIa presents the figures for the average marginal tax rate for each group. ${ }^{23}$ For high-income women there is an average reduction of 13.9 percentage points. For $75^{\text {th }}$ percentile women, the corresponding figure is 4.1 percentage points, for a relative reduction of 9.8 percentage-points. For $90^{\text {th }}$ percentile women, there is a relative decline of 6.9 percentage points. Table IIb presents the implied change in the after-tax wage

${ }^{23}$ These averages differ from those in Figure II (which presents the statutory federal tax schedule) because they include the secondary earner tax deduction and the FICA payroll tax. 
of high-income women: 22.6 percent relative to $75^{\text {th }}$ percentile women, and 16.8 percent relative to $90^{\text {th }}$ percentile women. $^{24}$

Table III reports the raw differences-in-differences estimates of the effect of the Tax Reform Act of 1986 on the labor supply of married women. Both the participation and the hours figures are presented. Panel A compares the changes in the labor force participation rate of high-income, $75^{\text {th }}$ and $90^{\text {th }}$ percentile women before and after the tax reform. Each cell contains the mean for the group labelled, along with standard errors and number of observations. There was a 5.3 percentage point increase in participation for the first control group compared with a 9.0 percentage point increase for the 'treatment' group. Thus, there is a 3.7 percentage point relative increase in the participation rate for upper-income women. The standard error for this increase is 2.8 percentage points; therefore it is significant only at the 10 percent confidence level for a one-tail test. The results are similar, and more significant, for the $90^{\text {th }}$ percentile control group.

Pre-treatment average participation rates for high-income and the control groups are quite different. This suggests that a different estimate of the latent variable 'participation of high-income women in the absence of the tax reforms" can be generated by assuming a constant growth rate, rather than a constant level change, across the two groups. This method suggests a relative increase in the average participation rate of 12.3 percent using the first control group and 13 percent using the second control group. I present these figures in Table III as well.

Panel B repeats the exercise for annual hours worked for women who are employed. Before I present the results, however, one point deserves mention. The participation results suggest that more women are entering the labor force during this period. Because these women may be different than women in the labor force prior to TRA86, the population of working women before and after the tax reforms is not directly comparable. Therefore we should be cautious in placing a causal interpretation results based only on working women. There is an increase of 54.8 hours for $75^{\text {th }}$ percentile women, and 163.3 hours for upper-income women. The relative increase, therefore, was 108.6 hours over the period

\footnotetext{
${ }^{24}$ I assume here that the relative gross market wage remains constant over this period. Feenberg and Poterba (1993) show that after 1986, there was a sharp increase in wages accruing to individuals at the top of the income distribution. This may be due either to choices about compensation packages, to changes in labor supply, or more likely to both. If it is primarily the former, then the assumption of a constant relative market wage is clearly invalid.
} 
1983-85 to 1989-91, significant at the 10 percent level. Assuming that the hours of work grow at the same rate generates a relative increase of 9.4 percent. As expected, this effect is weaker for the second control group: $90^{\text {th }}$ percentile women received larger tax reductions than $75^{\text {th }}$ percentile women and therefore we might expect a labor supply response for them as well. The relative differences between the $75^{\text {th }}$ and $90^{\text {th }}$ percentile groups are not statistically significant, however.

Panel $\mathrm{C}$ compares the changes in total hours of work of each group. The figures here show that there was an increase of 121.2 hours for $75^{\text {th }}$ percentile women compared with 206 hours for upperincome women. Thus we find a relative increase of 84.8 hours, significant at the 10 percent level. Assuming a constant growth rate in average annual hours generates an increase of 22.8 percent. The implied labor supply elasticity with respect to the after-tax wage is therefore in the range of $0.6(.14 / .22)$ to 1 . The comparison with women at the $90^{\text {th }}$ percentile of the distribution is similar, although marginally significant only at the 20 percent confidence level.

The elasticity estimates above rely on the assumption that the relative gross market wage for the two groups remains constant over this period. This assumption may of course be validated by looking at the data. There are two problems with testing this hypothesis, however. First, wages for non-workers do not exist. Therefore we must make the assumption that the relative distribution of the potential market wage for nonparticipants did not shift over this period. Second, many workers are salaried, and as such they have no properly defined wage. I therefore follow standard methodology and construct a measure of the hourly wage by dividing wage and salary earnings by annual hours. Table IV presents the summary statistics. For the group of working women before and after the tax reforms, there is no relative change in average hourly earnings. With the $75^{\text {th }}$ percentile control, the differential is only $\$ .63$ (less than 5 percent). Essentially all the variation in after-tax wages across the treatment and the control groups derives from tax reductions in TRA86.

The picture which emerges from these figures is that the labor supply of high-income married women increased dramatically after TRA86. Moreover, this increase is substantially larger for women whose after-tax wages increased a lot than for women whose after-tax wages increased by less. The evidence suggests that the relative change in the after-tax wage is due primarily to changes in tax rates, rather than changes in hourly wages. Using women in the $75^{\text {th }}$ percentile control group, the magnitude of the response in labor supply is significant for both labor force participation and for hours of work 
conditional on participation. The second control group provides strong support for the participation effect, but is inconclusive on the hours of work effect.

Both the bias and the sampling variance on these figures can be reduced by controlling for demographic characteristics. This is done in the context of a regression framework, which I present in the following section.

\section{Regression Framework}

The treatment and the control groups differ in a number of demographic characteristics, therefore we might be concerned that the increase in the labor supply of high-income women is a response to something other than the tax reform. Given these differences, we could attempt to describe the change in the conditional distribution of hours within cells narrowly defined along various dimensions: age, education, family size, etc. Such an exercise will lead to groups consisting of exactly the same type of women, some of whom receive a tax cut and some of whom receive no change in their tax rate. If we then observe a similar response, we are more confident in placing a causal interpretation on the results. Given that TRA86 targeted such a small group, however, cell sizes are likely to be too small for this exercise. Therefore, we use a regression framework to control for the relevant demographic characteristics.

I consider now the estimation of both the participation and the hours equations. I analyze the binary choice of whether or not to participate in the labor force as a probit model, where

$$
P\left(l f p_{i t}=1\right)=\Phi\left(z_{i t}^{\prime} \alpha\right)
$$

and $i$ indexes the individual, $t$ indexes time, $l f p_{i t}$ is labor force participation, $\Phi($.$) is the distribution$ function for the standard normal, and $z_{i t}$ is a vector of observable characteristics. Since this is straightforward, I discuss only the estimation of the hours of work equation.

I estimate the hours equation by using observations on working women only. Conditional on participation, we observe only positive hours of work. What we observe then is a truncated density for hours of work. To motivate this framework, consider that the goal of this exercise is to describe the change in the density of labor supply by married women after 1986. If it can be established that the density of hours (conditional on observable characteristics) shifted to the right, then the story that TRA 86 
caused this shift can be told.

The density of the hours is assumed to be given by

$$
f\left(h_{i t}\right)=\left(\frac{1}{\sigma}\right) \frac{\varphi\left(\left(h_{i t}-x_{i t} \beta\right) / \sigma\right)}{\Phi\left(x_{i t} \beta / \sigma\right)}
$$

where $\varphi$ is the density function and $\Phi$ is the distribution function of the standard normal. The $\log$ likelihood function for this model will be given by the sum of the $\log$ of these densities.

$$
\ln L=-N T \ln \left[(2 \pi)^{1 / 2} \sigma\right]-\frac{1}{2} \sum_{i} \sum_{t}\left(\frac{h_{i t}-x_{i t} \beta}{\sigma}\right)^{2}-\sum_{i} \sum_{t} \ln \Phi\left(\frac{x_{i t} \beta}{\sigma}\right)
$$

Maximizing this likelihood function with respect to $\beta$ and $\sigma^{2}$ produces consistent and efficient estimates under the assumption of a truncated normal distribution for hours given participation. Using the estimated parameters of the hours equation, the conditional mean of hours can be calculated as

$$
E\left(h_{i t} \mid h_{i t}>0\right)=x_{i t} \hat{\beta}+\hat{\sigma} \lambda_{i t}
$$

where $\lambda_{\mathrm{it}}$ is the inverse mills ratio given by

$$
\lambda_{i t}=\frac{\varphi\left(x_{i t} \hat{\beta} / \hat{\sigma}\right)}{\Phi\left(x_{i t} \hat{\beta} / \hat{\sigma}\right)}
$$

I then combine the two sets of coefficients to calculate the unconditional mean of hours as

$$
E\left(h_{i t}\right)=\Phi\left(z_{i t}^{\prime} \hat{\alpha}\right) \cdot\left(x_{i t} \hat{\beta}+\hat{\sigma} \lambda_{i t}\right)
$$

where the vector $\beta^{\wedge}$ is generated by the truncated normal regression and the vector $\alpha^{\wedge}$ is from the probit. The advantage of estimating a probit for participation and a truncated normal for hours is that the coefficients in the participation equation $\alpha^{\wedge}$ are not restricted to be equal to those in the hours equation, as is the case in a censored Tobit model. The model used, however, is not free of restrictive assumptions either. The combination of the participation and the hours assumes that the errors in the participation and the hours regressions are uncorrelated. To gauge the importance of these assumptions, I compare the estimates from this two equation approach to those derived from a Tobit regression. 


\section{V.1 Specification}

Since the market wage is endogenous to the tax reforms, it does not enter into the estimated

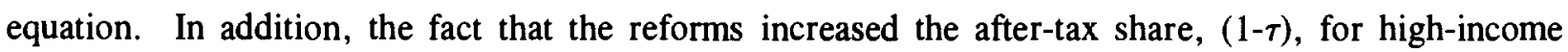
women significantly more than for other women lends itself easily to a nonparametric specification. The participation and the hours equations are specified as

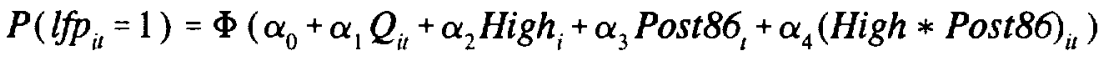

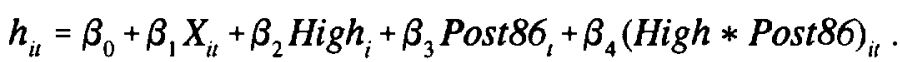

Labor force participation is a dummy equal to one if a woman reported working at least one hour during the year, even if she reported no earnings. ${ }^{25}$

The set of covariates $Q_{i t}$ and $X_{i t}$ are assumed to adequately control for selection into the treatment group. Since women in the high-income group are older and more educated on average than those in the control group, I include age and its square, and education and its square as covariates. The education variable is the number of completed years of schooling, recoded to match the 1992 CPS code, and then aggregated to 8 education classes. For the same reasons, I include the number of preschool children, a race dummy (equal to one if the woman is black), a dummy for residence in a central city and for residence in a metropolitan area. $X_{i t}$ includes, in addition, a set of 9 occupation dummies and a dummy for union status. Since there is a general trend in the labor supply of married women, I include separate year dummies (for 1983, 1984, 1989 and 1990). Finally, I include state effects to control for differences in regional work patterns and in state tax systems. ${ }^{26}$

$\mathrm{High}_{i t}$ is a dummy equal to one for women in the treatment group; any differences in labor supply preferences across the treatment and the control group will be reflected in its coefficient, $\alpha_{2} / \beta_{2}$. Both $\alpha_{2}$ and $\beta_{2}$ are expected to be negative, since high-income women will purchase more leisure than their counterparts further down the income distribution. Because the tax system is progressive, this coefficient

\footnotetext{
${ }^{25}$ Hours of work is constructed as the product of two variables asked in the March CPS : "usual hours worked per week last year" and "weeks worked last year".

${ }^{26}$ I do not address state tax changes during the period of analysis. This may cause a bias in my estimated elasticity since state tax reforms also differentially benefitted upper-income individuals.
} 
also reflects the incentive effects of higher marginal tax rates at the top of the distribution. If the substitution effects dominates, then it will reinforce the purchase of more leisure and make $\beta_{2}$ more negative than the pure income effect. If the income effect dominates, then it will dampen the effect and reduce the coefficient. Post $86_{i t}$ is equal to one for the post reform period: because participation and hours are increasing over time, $\alpha_{3}$ and $\beta_{3}$ should both be positive.

A test of the impact of the Tax Reform Act of 1986 is a test that high income married women increased their labor supply (relative to control group women) after 1986. It is a test that $\alpha_{4}>0$ and/or $\beta_{4}>0$. Using these parameters, one can then generate the net-wage elasticity of labor supply as the ratio of the relative percentage increase in labor supply of high-income women derived from the estimated labor supply equation to the relative percentage change in the after-tax wage for high-income women.

\section{Results}

\section{VI.1 Basic Regression Results}

I first present the results for labor force participation and then for annual hours of work conditional on employment and for total hours of work. In addition, I use throughout both the $75^{\text {th }}$ and the $90^{\text {th }}$ percentile groups as controls.

Table $\mathrm{V}$ presents estimates of the participation equation. Columns (1) and (2) use $75^{\text {th }}$ percentile women as the control group. First, I include only the treatment, time, interaction, and year dummies (for 1983, 1984, 1990 and 1991). Because separate year dummies are included, the time dummy is small in magnitude, and insignificant. The high-income dummy is large in magnitude, and strongly significant as expected. The coefficient on the interaction (high*post86) coefficient is 0.07 ; it is marginally significant at the 10 percent confidence level (for a one-tail test). In column (2) I add controls for individual characteristics, state, and location of residence (central city, MSA). Adding these controls increases both the size and the significance of the interaction (high*post86) coefficient: it becomes 0.10 (with a p-value of 0.09). Columns (3) and (4) report the results when the $90^{\text {th }}$ percentile group is used as a control. The similarity in these figures signals that the previous results are not driven by idiosyncratic shocks across $75^{\text {th }}$ percentile and high-income women.

All other variables in the probits, with the exception of education using the $90^{\text {th }}$ percentile control 
group, have their expected signs. Older women are more likely to be in the labor force, although this is a nonlinear relationship. As expected, the number of preschool children strongly reduces the probability of working. More educated women are more likely to be in the labor force, although again this relationship is clearly nonlinear (the coefficient is significant only in the square term when the $75^{\text {th }}$ percentile control group is used). When using the second control group, the impact of education on participation is negative: this effect is possibly due to the similarity in educational attainment of $90^{\text {th }}$ percentile and high-income women.

Using the probit coefficients, Table VIa reports predicted participation rates evaluated at the average characteristics of the sample. For high-income women, there is a predicted increase in participation of 3.7 percentage points $\left(8.1\right.$ percent); for $75^{\text {th }}$ percentile women, there is a predicted decrease in participation, although of less than 0.2 percentage points (driven by the negative time dummy). This generates a 3.9 percentage-point ( 8.4 percent) relative increase in predicted participation over the period. I also use the coefficients to predict participation for each individual in the sample: this procedure generates an average predicted increase of 8.7 percent. ${ }^{27}$

In order to calculate the participation elasticity, I use the change in the first hour after-tax wage. Assuming a constant relative market wage for the two groups over this period, I calculate the percentage change in the after-tax wage as the percentage change in the after-tax share (1- $\tau)$. The average first hour marginal tax rate for high-income women fell by 26.5 percent; for the first control group, the decline was 6.2 percent (again, including the secondary earner tax deduction and social security taxes). The relative percentage change in the first hour after-tax wage was therefore 20.3 percent. This generates an elasticity of participation of $0.4(0.08 / 0.2)$. The predicted increase of 10.9 percent using the second control group implies an elasticity of participation of 0.6 for high-income women. ${ }^{28}$

Table VII presents the results for hours of work conditional on participation. The coefficient on (high*post86) represents the increase in desired hours of work of high-income women relative to the

\footnotetext{
${ }^{27}$ The concern here is that the results may be driven by the nonlinearity of the probit model, since the predicted relative change in participation can be different from zero even if the interaction coefficient (high*post86) is zero. I therefore predict participation rates under the assumption of a zero coefficient on the interaction term: in each case, there is no difference in the predicted participation response of high-income women relative to control-group women.

${ }^{28}$ The implied elasticity of non-participation is in the range of 0.3 to 0.5 .
} 
control group. There is a statistically significant relative increase of 142.8 hours (with a p-value of 0.05 ). Controlling for demographic characteristics, state and location of residence (MSA and central city), and occupation does not alter the results in any significant way. The response in hours worked falls to 115.32, but remains statistically significant with a p-value of 0.07 .

All variables in the truncated regression, except for education, have the expected sign and are significantly different from zero. The effect of education on hours of work for these women is flat up to the 13-15 education level; however, above that there is a sharp increase in hours of work. Therefore, the results here are driven by the very high hours worked by women with a graduate degree. As expected, more children under 6 reduces the number of hours worked by women. One pattern to note from the participation and the hours results is that women whose husbands are self employed are more likely to be labor force participants, although they work fewer hours once in the labor force.

The increase in observed hours of work is generated by combining the coefficients from the truncated normal regression with the participation coefficients. Table VIIIa presents the figures. Evaluating participation and hours at the average of the sample, there is a predicted increase of $\mathbf{9 8 . 5}$ hours (19.4 percent) for high-income women, and an increase of 8.7 hours ( 1 percent) for the first control group due to the tax reforms of 1986. The relative increase of 89.7 hours (18.4 percent) translates into a net-wage elasticity of approximately 0.8 (see Table VIIlb). ${ }^{29}$ In the case of hours of work, the second control group provides only weak supportive evidence; it does not overturn the results, however. The magnitude of the response is quite similar ( 75 hours, or 16.9 percent using predicted hours of work pre TRA86 as the base), but the standard errors are large. This result is not entirely unexpected; since allocation to the treatment group is based on other household income, some women in $90^{\text {th }}$ to $95^{\text {th }}$ group may face tax reductions as large as those at the very top of the income distribution. ${ }^{30}$

I also estimated the hours equation using the more restrictive Tobit. Table IX presents those results. For the $75^{\text {th }}$ percentile, the coefficient on (high*post86) is 172.7 for the basic regression, and

${ }^{29}$ Predicting total hours of work for each women and averaging over the sample generates very similar responses.

30 Estimating the hours equation by ordinary least squares generates similar results. OLS estimates are biased if there is self-selection into the labor force, however. TRA86 does not allow me to address this issue, however, since a selection model would not be not identified: there is only one source of exogenous variation to identify the response of both participation and hours of work. 
189.4 (with a p-value of 0.01) when state and demographic controls are added in. Table Xa presents the predicted hours evaluated at the 'average' characteristics in the sample. The figures are quite similar to those calculated using the coefficients from the probit and the truncated normal. ${ }^{31}$ There is an estimated increase of 101.7 hours ( 23 percent) for high-income women, and 10.3 hours ( 1 percent) for the $75^{\text {th }}$ percentile group. The relative increase of 22 percent implies that the total elasticity of labor supply with respect to the net-wage is 1 . These results are robust to the control group used. The Tobit results are similar to the basic ones, although they are somewhat stronger. Nonetheless, it is comforting that these results are not very different.

The conclusion to draw from these results is that controlling for demographic characteristics does not alter the basic differences-in-differences estimates of the impact of TRA86 on the labor supply of married women.

\section{VI.2 Labor Demand Shocks}

A second potential explanation for the relative increase in hours of work for high-income women is that their relative labor demand increased during the period of the reform. In this case the basic specification would overestimate the labor supply response to TRA86. I therefore examine the possibility that relative labor demand shocks are the cause of the increase in participation and in hours of work over this period.

Since women in the high-income group are more educated, and education is the most direct channel through which labor demand shocks operate, a convenient way of addressing this problem is to interact the education variable with the post 86 dummy. I therefore estimate the following equation:

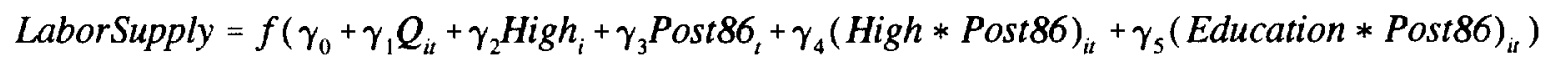

If returns to education increased over the period, then we should expect the coefficient $\gamma_{5}$ to be positive, and $\gamma_{4}$ to be smaller in magnitude than in the basic specification. Table XI presents the results when this interaction variable is included. There is no qualitative change in the basic conclusions, although as expected the magnitudes are somewhat different. The impact of this additional variable seems to be in

${ }^{31}$ In each case, the likelihood value for the tobit is less than the sum of the probit and truncated normal likelihood values. Therefore, we can reject the censored tobit in favor of the separate participation and truncated normal specifications. 
the participation equation with the $75^{\text {th }}$ percentile control group. Column (1) presents the participation results. $\gamma_{4}$ remains positive although it is imprecisely estimated; it is essentially halved from 0.10 to 0.05 (with a standard error of 0.8 ). ${ }^{32}$ I present the relative change in the probability of participation for high-income women, evaluated at the average characteristics of the sample, and the implied elasticity of participation. ${ }^{33}$

\begin{tabular}{l|c|c}
\hline \hline Control Group & $\begin{array}{c}\text { Differences-in- } \\
\text { Differences }\end{array}$ & Elasticity \\
\hline $75^{\text {th }}$ Percentile Group & $4.3 \%$ & 0.2 \\
\hline $90^{\text {th }}$ Percentile Group & $11.4 \%$ & 0.6 \\
\hline \hline
\end{tabular}

The first point to note is that the predicted participation response when using the $90^{\text {th }}$ percentile control group does not change: the elasticity remains at 0.6 . When using the $75^{\text {th }}$ percentile control group, we find a much smaller participation effect. Clearly part of the participation of high-income relative to $75^{\text {th }}$ percentile income women is by more educated high-income women. However, interpreting this result as a response to changes in the returns to education requires an explanation of the results on hours of work. Column (2) of Table XI presents the results for the truncated hours regression. The coefficient on the (education*post86) variable is actually negative, although negligible in magnitude and statistically not different from zero. Therefore, including this interaction leads to no change in the increase in hours for high-income women over the period (the increase becomes 118.9, 3 hours more than the basic result). The same result is seen when using the $90^{\text {th }}$ percentile control group.

While there is evidence that part of the relative participation response is by more educated highincome women, it is not clear that changes in the skill premium is the explanation. There are two possible objections to interpreting this result as a response to changes in the returns to education. First, evidence on average hourly wages suggests that there is no relative change in the returns to education

\footnotetext{
32 The likelihood ratio test statistic comparing the restricted estimates in column (2) of Table $V$ is with the unrestricted estimates in column (1) of Table IX is 6.0. The critical value for a $\chi^{2}$ with 1 degree of freedom is 3.84. Therefore the basic specification is rejected in favor of the expanded one. This test fails to reject for the $90^{\text {th }}$ percentile group.

${ }^{33}$ Predicting the probability of participation for each woman and averaging over the sample generates very similar results.
} 
across working married women in the two groups. The objection to this interpretation of the wage data is of course that the observed average hourly wage represents an equilibrium outcome, so both labor demand and supply may have increased during this period. Also, average hourly wages are measured with error, so it is unclear what conclusions we can draw from them. A second reason why we might not expect labor demand shocks to matter for the analysis is that the differences in the educational attainment of women in the treatment and the control groups are actually quite small. Both groups have some college education (high-income women have 14.8 years of education, whereas $75^{\text {th }}$ and $90^{\text {th }}$ percentile women have 13.3 and 14.1 years of education respectively). One would require a significant change in the skill premium for individuals with three as opposed to one year of college education to alter the basic results. ${ }^{34}$

\section{VI.3 Trends Prior to TRA86}

The third explanation for the basic results is that $75^{\text {th }}$ and $90^{\text {th }}$ percentile income women do not adequately control for the trend in high-income women's labor supply. If these results are not replicated by analyzing the behavior of the two groups in a period with no major tax reforms, then we should feel more confident that our interpretation of the observed change in labor supply is valid. The ideal exercise here would compare data 4 years apart prior to 1986 . The 1980's is an especially difficult period to use for this exercise, however, primarily because of a major tax change in 1981, and a severe recession in 1981-1982. This restricts the period one could use to analyze the relationship between the treatment and the control groups, and therefore the power of this test. Nonetheless, I estimate a simple differences-indifferences regression for 1983 and 1985 . Note that even during this short period, relative marginal tax rates did not remain perfectly constant. The reduction in marginal tax rates in ERTA was phased in between 1981 and 1984 .

Table XII presents the regression results for the period before TRA86. In general, the point estimates are much smaller than for the TRA86 changes, although the standard errors are very large. The imprecision in these estimates is due partially to the smaller sample size, however. Using the $75^{\text {th }}$ percentile control group, the interaction coefficient in the probit is 0.05 , approximately one-third its

\footnotetext{
${ }^{34}$ There remains the worry that increasing within-group wage inequality may explain part of the response in the labor supply of the high-income group.
} 
standard error (.13). The participation effect is therefore zero. In the basic hours regression, the interaction (High*T85) coefficient is actually negative using both $75^{\text {th }}$ and $90^{\text {th }}$ percentile groups. The results on the hours regressions, however, are extremely sensitive to the set of included regressors. I report here the basic (no demographic controls), as well as the expanded (both excluding and including occupation controls) results. The (high*T85) coefficient varies from -29.6 hours (basic) to -3.6 (no occupation dummies) to 52 hours (with occupation dummies). In all cases, the standard errors are approximately 130 . For the $90^{\text {th }}$ percentile, the pattern of results is similar; here the results are even more sensitive to the inclusion of various regressors.

Although not a powerful test, the evidence does not suggest that the labor supply of high-income women was following a different trend than the labor supply of women in the two control groups. The sensitivity of the point estimates, however, suggests that we interpret the TRA86 results with some caution.

\section{VI.4 Specification Checks}

Maximum Likelihood estimates are inconsistent if the parametric form of the error term is misspecified. I therefore estimated both the participation and the hours equations under different distributional assumptions for the error term. Estimating the participation equation as a logit generates the same coefficients as the probit, up to a scalar. Assuming a lognormal distribution for the error term in the hours of work equation generates coefficients which are of the same order of magnitude as the truncated normal, although standard errors are larger. It should not be surprising that the specification of the error distribution is not critical to the results. Newey, Powell and Walker (1990) show this to be the case in 'selection' models of labor supply.

Because the treatment and control groups are chosen on the basis of income, it is not clear whether other household income should be included as a regressor in addition to the high-income dummy. The large standard deviation on other-household income for the treatment group suggests that we may be able to estimate an income effect based on variation in the labor supply of this group. As a specification check, I re-estimated both the participation and hours equations including other household income as a regressor. When included as a continuous variable, income reduces both the probability of participation in the labor force, and the number of hours worked. The coefficient is small in magnitude 
and not significantly different from zero once selection into a group is controlled for, however. Including income in these equations changes none of the key coefficients; only the standard error on the highincome dummy is increased. Likelihood ratio tests fail to reject the specification that excludes other household income for both participation and hours of work. ${ }^{35}$

Given the education results in the basic regressions, I re-estimated the participation and hours equations using education class dummies rather than actual years of education. As expected, I find that the nonlinearity in the relationship between education and participation is reflected in the dummy coefficients. The coefficients on the education dummies increase in value with each class of education. The very high participation rate and hours of work for women with 18 or more years of education seem to be driving the results on the education variables. Estimating the regression with education dummies changes neither the coefficients on other variables nor the likelihood value.

Bosworth and Burtless (1992) show that older women have been increasing their labor supply significantly over the period of analysis at a faster rate than younger women. If this is the case, we should allow for different responses by different cohorts of women. To address the potential problem of differing responses by older women, I re-estimated the basic equation interacting the post86 dummy with cohort (defined by 5 year intervals). Again this exercise had little impact on the key coefficients.

There remains one testable hypothesis: the relative increase in labor supply by high-income women is due to a contemporaneous shock that is correlated with observable characteristics. We need not have a good story for why this might have occurred but to the extent that the response varies by race, say, we would be suspicious of the interpretation that TRA86 caused the observed shift in labor supply. To check this possibility, I interacted both race and children under 6 variables with the time dummy. Again the results were relatively unaffected.

\section{VI.5 Summary}

This paper has made an attempt at identifying the impact of tax reform on the incentives to supply labor by married women. There are several plausible estimates of the impact of TRA86; all point to the

\footnotetext{
${ }^{35}$ A proper treatment of taxes and labor supply would incorporate virtual income, the value of the implicit subsidy given to taxpayers due to the progressivity of the tax system. Given that TRA86 flattened the tax schedule, we should expect a relative decrease in virtual income for upper-income women. The results above suggest that failing to account for virtual income will not cause any bias in the estimates responses, however.
} 
general conclusion that the labor supply of married women increased following the reduction in marginal tax rates. I present here the figures for the increase in labor force participation and in total labor supply.

\begin{tabular}{l||c|c|c|c}
\hline \hline Control Group & Raw Data & $\begin{array}{c}\text { Demographic } \\
\text { controls }\end{array}$ & $\begin{array}{c}\text { Adding Education } \\
\text { Interaction }\end{array}$ & Elasticity \\
\hline \hline
\end{tabular}

A: Participation Response:

\begin{tabular}{l||c|c|c|c}
\hline No Control Group & $19.5 \%$ & - & -- & - \\
\hline $75^{\text {th }}$ Percentile & $12.3 \%$ & $8.4 \%$ & $4.3 \%$ & $0.2-0.4$ \\
\hline $90^{\text {th }}$ Percentile & $13.0 \%$ & $10.9 \%$ & $11.4 \%$ & 0.6 \\
\hline \hline
\end{tabular}

B: Total Labor Supply:

\begin{tabular}{l||c|c|c|c}
\hline No Control Group & $34.5 \%$ & - & -- & - \\
\hline $75^{\text {th }}$ Percentile & $22.8 \%$ & $18.4 \%$ & $12.3 \%$ & $0.6-1.0$ \\
\hline $90^{\text {th }}$ Percentile & $19.8 \%$ & $16.9 \%$ & $14.6 \%$ & $0.9-1.0$ \\
\hline \hline
\end{tabular}

The top panel shows the relative increase in the labor force participation rate of high-income, married women; the bottom panel presents the corresponding figures for the increase in annual hours of work. The relative participation increase of 19.5 percent ( 9 percentage points), and the relative hours increase of 34.5 percent ( 206 hours per year) are contaminated by both the trend and any response to the changing returns to education over the period. Controlling for observable characteristics reduces the estimated participation response to 8 percent using the first control group, and 10.9 percent using the second control group. The corresponding response in total labor supply is in the range of 17 to 18 percent. Allowing for the effect of changes in the returns to education reduces by one half the labor supply effect for the $75^{\text {th }}$ percentile group: all of this effect is operating through the participation decision. There is no analogous effect for the $90^{\text {th }}$ percentile group; this result is not surprising since the difference in average education levels between this control group and the treatment group is only half a year. 


\section{Conclusion and Policy Implications}

Using the Tax Reform Act of 1986 as a natural experiment and a differences-in-differences methodology, I analyze the responsiveness of married women's labor supply to a change in the tax rate. This approach allows me to estimate a policy parameter without explicitly parameterizing the tax system, and therefore without relying on functional form assumptions for identification. I estimate an elasticity of total labor supply with respect to the after-tax wage for high-income, married women of approximately 0.8 , and a participation elasticity of 0.4 . These estimates are fairly robust to the control group used and to various specification checks.

These results have several implications for existing estimates of taxes and labor supply. First, the results are quite consistent with elasticities based on cross-sectional data. In fact, if we believe that labor supply responsiveness varies across the income distribution and therefore that the labor supply elasticity in a cross section is a weighted average of elasticities at different points along the income distribution, then estimates in this paper are somewhat small. The negative income tax experiments suggest that labor supply elasticities for poor married women are relatively small, so we should expect that upper income women would have elasticities that are larger than average.

The second point of interest is the composition of the labor supply elasticity. Previous research suggests that the participation decision is far more elastic than are hours conditional on working (Mroz 1987, Triest 1990). My results suggest that, for high-income women, the participation decision is only slightly more sensitive to taxes than the hours decision. Using the $75^{\text {th }}$ percentile control group, the participation elasticity is exactly half the total elasticity, whereas using the $90^{\text {th }}$ percentile control group, the participation elasticity is approximately 60 percent of the total elasticity.

These results also have implications for the likely impact of the recent increase in marginal tax rates for those at the top of the income distribution. A direct calculation suggests the 16 percent decrease in the after-tax wage (due to OBRA93) will reduce the labor supply of high-income, married women by roughly 13 percent; approximately half of this effect is due to reduced participation. Two caveats are in order, however. First, the estimates in this paper are reduced form estimates and therefore can only be suggestive of the magnitude of the response to tax changes in OBRA93. Second, the distinction between participation and hours of work is relevant here because there may be an important asymmetry: reductions in marginal tax rates induce women to enter the labor force, but increases in marginal tax rates 
may not induce them to exit to the same extent. Evidence suggests that current labor force participation is a strong predictor of past participation so once in the labor force, participants are likely to remain in the labor force (Mroz 1987). Therefore, the behavioral responses to OBRA93 are likely to be somewhat smaller than is suggested by these estimates. In addition, the revenue loss due purely to the reduction in labor supply of high-income women is likely to be small since these women earn less than 10 percent of total family income. ${ }^{36}$

At the same time, however, higher taxes may reduce labor supply in ways that are not captured by hours of work or participation. The concept of labor supply is of course far more general than hours of work or participation: higher taxes will affect worker productivity, human capital accumulation, and occupational choice. Analyses of behavioral responses based on hours of work elasticities therefore describe only the most basic incentive effects of taxation.

Two final points are in order. The measured elasticity does not necessarily apply to the population of married women, and as such is less useful for analyzing the incentive effects of less targeted policies such as the Clinton health care plan. The Economic Recovery Tax Act of 1981 (ERTA) reduced marginal tax rates along the entire income distribution; this policy change could be used to estimate an average elasticity for all married women. ${ }^{37}$ Second, both ERTA and TRA86 could be used to analyze labor supply responsiveness of other demographic groups. Heckman (1993) notes that there is little evidence on the responsiveness of male labor force participation to changes in tax rates. Given that male labor force participation rates have been declining over the past two decades, we should worry more about the impact of taxes on their participation decision. I plan to pursue this topic in future research.

\footnotetext{
${ }^{36}$ As a consequence, the increase in labor supply of married women is not likely to be an important part of the explanation for the increase in the share of AGI going to those at the top of the income distribution over the 1986 period.

${ }^{37}$ See Eissa (1994).
} 


\section{Bibliography}

Aaron, Henry, "Lessons for Tax Reform," In Slemrod, Joel, ed., Do Taxes Matter? The Tax Reform Act of 1986, Cambridge: MIT Press, 1990.

Ashenfelter, Orley and James Heckman, "The Estimation of Income and Substitution Effects in a Model of Family Labor Supply," Econometrica, January 1974.

Blundell, Richard, Alan Duncan and Costas Meghir, "Robust Estimation of Labour Supply Responses in the Presence of Taxes," unpublished paper, March 1993.

Boskin, Michael, J., "The Economics of Labor Supply," in G.G. Cain and H.W. Watts (eds.) Income Maintenance and Labor Supply. Chicago: Markham, 1973.

Bosworth, Barry, and Gary Burtless, "Effects of Tax Reform on Labor Supply, Investment, and Saving," Journal of Economic Perspectives, Winter 1992.

Burtless, Gary, "The Supply Side Legacy of the Reagan Years: Effects on Labor Supply," In Sahu, A.P, and Ronald Tracy, eds., The Economic Legacy of the Reagan Years: Euphoria or Chaos?, New York: Praeger, 1991.

Cogan, John F., "Fixed Costs and Labor Supply," Econometrica, Vol49, 1981.

Deaton, Angus S. "Panel Data from Time Series of Cross-Sections," Journal of Econometrics, 1985.

Eissa, Nada, "Taxes and Labor Supply of Married Women: Evidence from the Economic Recovery Tax Act of 1981," University of California, Berkeley mimeo, 1994.

Feenberg, Daniel, "Are Tax Price Models Really Identified: The Case of Charitable Giving," National Tax Journal, December 1987.

Taxpayers," Tax Policy and the Economy, NBER: Cambridge, 1993.

Feldstein, Martin, "The Effect of Marginal Tax Rates on Taxable Income: A Panel Study of the 1986 Tax Reform Act, NBER Working Paper \#4496, 1993.

---------, "Clinton's Revenue Mirage," Wall Street Journal, April 6, 1993.

and Andrew Samwick, "Social Security Rules and Marginal Tax Rates," National Tax Journal, March 1992.

Hall, Robert, E., "Wages, Income and Hours of work in the US Labor Force," in G.G. Cain and H.W. Watts (eds.) Income Maintenance and Labor Supply. Chicago: Markham, 1973.

Hausman, Jerry, "The Effect of Wages, Taxes, and Fixed Costs on Women's Labor force Participation, Journal of Public Economics, vol 14, 1980. 
------, "Labor Supply," In Aaron, Henry and Joseph Pechman, eds., How Taxes Affect Economic Behavior, Brookings Institution, 1981.

-----, "Taxes and Labor Supply." In Auerbach, Alan and Martin Feldstein, eds., Handbook of Public Economics, Volume I, Amsterdam, 1985.

-------, and James Poterba, "Household Behavior and the Tax Reform Act of 1986," Journal of Economic Perspectives, Summer 1987.

------------, and Paul Ruud, "Family Labor Supply with Taxes, " American Economic Review, May 1984.

-----, and David Wise, "Social Experimentation, Truncated Distributions , and Efficient Estimation, Econometrica, vol 45, 1977.

Heckman, James, "Three Essays on Household Labor Supply and the Demand for Market Goods," Princeton University, 1971.

-------------, "Shadow Prices, Market Wages, and Labor Supply," Econometrica, vol 6, 1974.

-----, "Comment," in Feldstein, Martin, ed. Behavioral Simulations in Tax Policy Analysis, University of Chicago Press, 1982.

--------, "What Has Been Learned About Labor Supply in the Past Twenty Years?, American Economic Review, May 1993.

Horney, Mary Jean nd Marjorie B. McElroy, "A Nash-Bargained Linear Expenditure System: Household Demand for Leisure Goods," Center for Mathematical Studies in Business and Economics, Department of Economics and Graduate School of Business, University of Chicago, Report 8041.

Katz, Lawrence, and Kevin Murphy, "Changes in Relative Wages, 1983-1987: Supply and Demand Factors," Quarterly Journal of Economics, February 1992.

Killingsworth, "Labor Supply," Cambridge Surveys of Economic Literature, 1983.

------------, and James Heckman, "Female Labor Supply: A Survey," in Ashenfelter, Orley and Richard Layard, Handbook of Labor Economics, Volume I, 1987.

Kooreman, Peter and Arie Kapteyn, "On the Empirical Implementation of Some Game Theoretic Models of Household Labor Supply, The Journal of Human Resources, Fall 1990.

Kuttner, Bob, "A Supply-Side Break for the Rich? It's Been Tried Before and Didn't Work," Boston Globe, April 23, 1993.

Lindsey, L., "Is the Maximum Tax on Earned Income Effective?," National Tax Journal, June 1981.

---------, "Individual Taxpayer Response to Tax Cuts, 1982-1984: With Implications for the Revenue Maximizing Tax Rate," Journal of Public Economics, July 1987. 
, "Did ERTA Raise the Share of Taxes Paid by Upper Income Taxpayers? Will TRA be a Repeat?" In Summers, Lawrence, ed., Tax Policy and the Economy, 2, Cambridge: MIT Press, 1988.

-------, "The Growth Experiment," New York:Basic Books, 1990.

MaCurdy, Thomas, "An Empirical Model of Labor Supply in a Lifecycle Setting," Journal of Political Economy, 1981.

Economic Review, May 1992.

David Green and Harry Paarsch, "Assessing Empirical Approaches for Analyzing Taxes and Labor Supply," The Journal of Human Resources, Summer 1990.

Maddala, G.S., Limited Dependent and Qualitative Variables in Econometrics, Econometric Society Monographs, Cambridge University Press, 1983.

McElroy, Marjorie, "The Empirical Content of Nash-Bargained Household Behavior," The Journal of Human Resources, Fall 1990.

, "Empirical Results from Estimates of Joint Labor Supply Functions of Husbands and Wives," Appendix to A Survey of Labor Supply Models: Theoretical Analysis and First Generation Empirical Results in ed Ehrenberg, Ronald, G. "Research in Labor Economics," Volume 4, JAI Press, 1981.

Mroz, Thomas, "The Sensitivity of An Empirical Model of Married Women's Hours of Work to Economic and Statistical Assumptions," Econometrica, July 1987.

Murphy, Kevin and Finis Welch, "The Structure of Wages," Quarterly Journal of Economics, February 1992.

Navratil, John F., "Evidence of Individual Taxpayer Behavior from Panel Tax Return Data," Harvard University mimeo, March 1994.

Newey, Whitney, James Powell and James Walker," Semiparametric Estimation of Selection Models: Some Empirical Results," American Economic Review, May 1990.

Rosen, Harvey, "Taxes in a Model of Joint Wage-Hours Determination," Econometrica, vol44, 1976.

-, "What Is Labor Supply and Do Taxes Affect It?," American Economic Review, May 1980.

-, "Tax Illusion and the Labor Supply of Married Women," Review of Economics and Statistics, 1976. 
Rosenbaum, Paul, "The Role of the Second Control Group in an Observational Study," Statistical Science, 1987.

Triest, Ronald, "The Effect of Income Taxation on Labor Supply in the United States," The Journal of Human Resources, Summer 1990.

Wallace and Wasylenko, "Tax Reform 1986 and Marginal Welfare Changes for Labor," Southern Economic Journal, July 1992. 
Table I

Summary Statistics

\begin{tabular}{|c|c|c|c|}
\hline \multirow[t]{2}{*}{ VARIABLE } & \multicolumn{3}{|c|}{ GROUP } \\
\hline & HIGH & $75^{\text {th }}$ PERCENTILE & $90^{\text {th }}$ PERCENTILE \\
\hline Age & $\begin{array}{l}47.6 \\
(.25)\end{array}$ & $\begin{array}{l}40.6 \\
(.11)\end{array}$ & $\begin{array}{l}42.9 \\
(.11)\end{array}$ \\
\hline Education & $\begin{array}{l}14.8 \\
(.06)\end{array}$ & $\begin{array}{l}13.3 \\
(.03)\end{array}$ & $\begin{array}{l}14.1 \\
(.03)\end{array}$ \\
\hline Preschool Children & $\begin{array}{l}0.18 \\
(.01)\end{array}$ & $\begin{array}{l}0.35 \\
(.01)\end{array}$ & $\begin{array}{l}0.31 \\
(.01)\end{array}$ \\
\hline Family Size & $\begin{array}{l}2.88 \\
(.03)\end{array}$ & $\begin{array}{l}3.21 \\
(.01)\end{array}$ & $\begin{array}{l}3.18 \\
(.01)\end{array}$ \\
\hline Total Family Income & $\begin{array}{c}131,651 \\
(944)\end{array}$ & $\begin{array}{c}47,101 \\
(128)\end{array}$ & $\begin{array}{c}67,211 \\
(164)\end{array}$ \\
\hline Other Household Income & $\begin{array}{c}122,790 \\
(854)\end{array}$ & $\begin{array}{c}37,223 \\
(17.3)\end{array}$ & $\begin{array}{l}57,386 \\
(59)\end{array}$ \\
\hline Hours & $\begin{array}{l}696.0 \\
(23.8)\end{array}$ & $\begin{array}{l}1092.4 \\
(10.7)\end{array}$ & $\begin{array}{l}939.2 \\
(11.0)\end{array}$ \\
\hline Occupation & & & \\
\hline $\begin{array}{l}\text { Executive,Administrative } \\
\text { and Managerial (\%) }\end{array}$ & 19.1 & 11.8 & 15.5 \\
\hline Professional Specialty (\%) & 31.2 & 21.7 & 28.4 \\
\hline $\begin{array}{l}\text { Administrative Support, } \\
\text { including Clerical (\%) }\end{array}$ & 28.6 & 34.4 & 31.9 \\
\hline Service Occupations (\%) & 4.0 & 9.2 & 5.3 \\
\hline Observations & 1474 & 7412 & 7343 \\
\hline
\end{tabular}

Data are from the March Current Population Surveys (CPS) from survey years 1984-1986 and 1990-1992. The sample includes women between the ages of 20-64, residing with their (employed) spouses at the time of the interview. The sample excludes women who were ill or disabled during the previous year, women who were self-employed, and women working 4160 hours per year ( 52 weeks per year at 80 hours per week) or more. The treatment group $(\mathrm{HIGH})$ is women at or above the $99^{\text {th }}$ percentile of the income distribution of married women, The control groups $75^{\text {th }}$ PERCENTILE and $90^{\text {th }}$ PERCENTILE are, respectively, within 5 percentile points above $75^{\text {th }}$ and $90^{\text {th }}$ percentiles of the same income distribution. Education averages exclude 1992. All income figures are in 1985 dollars. Standard errors are in parentheses. Means are unweighted. 
Table Ila

Marginal Tax Rate

\begin{tabular}{l||cccc} 
Group & $\begin{array}{l}\text { Before } \\
\text { TRA86 }\end{array}$ & $\begin{array}{c}\text { After } \\
\text { TRA86 }\end{array}$ & Change & $\begin{array}{c}\text { Relative } \\
\text { Change }\end{array}$ \\
\hline \hline \multirow{3}{*}{ High } & & & & \\
& & .382 & -.139 & \\
& $(521$ & $(.001)$ & & \\
$75^{\text {th }}$ & $(.002)$ & & $-.002)$ & $\mathbf{- . 0 9 8}$ \\
Percentile & & .324 & $(.001)$ & $\mathbf{( . 0 0 2 )}$ \\
& .365 & $(.001)$ & & \\
$90^{\text {th }}$ & $(.001)$ & & -.07 & $\mathbf{- . 0 6 9}$ \\
Percentile & .430 & .360 & $(.001)$ & $\mathbf{( . 0 0 2 )}$ \\
& $(.001)$ & $(.001)$ & & \\
\hline \hline
\end{tabular}

The marginal tax rate is calculated using family wage and salary, self-employment, interest, dividend, farm and social-security income. I assume all couples file jointly, and that all itemize their deductions. Itemized deductions and capital gains are imputed using Statistics of Income data. These figures include the secondary earner deduction, as well as social security taxes. Standard errors are in parentheses. Before TRA86 is tax years 1983-1985; After TRA86 is tax years 1989-1991.

Table IIb

After-Tax Wage

\begin{tabular}{l||cc} 
Group & Change & Relative Change \\
\hline \hline High & $29.1 \%$ & \\
$75^{\text {th }}$ & $6.5 \%$ & $22.6 \%$ \\
Percentile & $12.3 \%$ & $16.8 \%$ \\
$90^{\text {th }}$ & & \\
Percentile & & \\
\hline \hline
\end{tabular}

I assume that the real average market wage for each group is constant. Therefore, the percent-change in the after-tax wage is calculated as the percent-change in the 'after tax share'- $(1-\tau)$, where $\tau$ is the marginal tax rate. 
Table III

Differences-in-Differences Estimates

CPS Married Women Before and After TRA86

A: Labor Force Participation

\begin{tabular}{|c|c|c|c|c|}
\hline Group & $\begin{array}{l}\text { Before } \\
\text { TRA86 }\end{array}$ & $\begin{array}{c}\text { After } \\
\text { TRA86 }\end{array}$ & Change & $\begin{array}{l}\text { Difference-in- } \\
\text { Difference }\end{array}$ \\
\hline High & $\begin{array}{c}0.464(.018) \\
{[756]}\end{array}$ & $\begin{array}{c}0.554(.018) \\
{[718]}\end{array}$ & $\begin{array}{c}0.090(.025) \\
\quad\{19.5 \%\}\end{array}$ & \\
\hline $\begin{array}{l}75^{\text {th }} \\
\text { Percentile }\end{array}$ & $\begin{array}{c}0.687(.010) \\
{[3799]}\end{array}$ & $\begin{array}{c}0.740(.010) \\
{[3613]}\end{array}$ & $\begin{array}{c}0.053(.010) \\
\{7.2 \%\}\end{array}$ & $\begin{array}{c}0.037(.028) \\
\{12.3 \%\}\end{array}$ \\
\hline $\begin{array}{l}90^{\text {th }} \\
\text { Percentile }\end{array}$ & $\begin{array}{c}0.611(.010) \\
{[3765]}\end{array}$ & $\begin{array}{c}0.656(.010) \\
{[3584]}\end{array}$ & $\begin{array}{c}0.045(.010) \\
\{6.5 \%\}\end{array}$ & $\begin{array}{c}0.045(.028) \\
\{13 \%\}\end{array}$ \\
\hline
\end{tabular}

B: Hours Conditional on Employment

\begin{tabular}{|c|c|c|c|c|}
\hline Group & $\begin{array}{l}\text { Before } \\
\text { TRA86 }\end{array}$ & $\begin{array}{c}\text { After } \\
\text { TRA86 }\end{array}$ & Change & $\begin{array}{l}\text { Difference-in } \\
\text { Difference }\end{array}$ \\
\hline High & $\begin{array}{c}1283.0(46.3) \\
{[351]}\end{array}$ & $\begin{array}{c}1446.3(41.1) \\
{[398]}\end{array}$ & $\begin{array}{c}163.3(61.5) \\
\{12.7 \%\}\end{array}$ & \\
\hline $\begin{array}{l}75^{\text {th }} \\
\text { Percentile }\end{array}$ & $\begin{array}{c}1504.1(14.3) \\
{[2610]}\end{array}$ & $\begin{array}{c}1558.9(13.9) \\
{[2676]}\end{array}$ & $\begin{array}{c}54.8(20.0) \\
\{3.6 \%\}\end{array}$ & $\begin{array}{c}108.6(65.1) \\
\{9.4 \%\}\end{array}$ \\
\hline $\begin{array}{l}90^{\text {th }} \\
\text { Percentile }\end{array}$ & $\begin{array}{c}1434.1(16.4) \\
{[2303]}\end{array}$ & $\begin{array}{c}1530.1(15.9) \\
{[2348]}\end{array}$ & $\begin{array}{c}96.0(22.8) \\
\{6.8 \%\}\end{array}$ & $\begin{array}{c}67.3(64.8) \\
\{6.2 \%\}\end{array}$ \\
\hline
\end{tabular}

Each cell contains the mean for that group, along with standard errors in (), number of observations in [], and \% increase in \{\}. Means are unweighted. 
C: Annual Hours

\begin{tabular}{|c|c|c|c|c|}
\hline Group & $\begin{array}{l}\text { Before } \\
\text { TRA86 }\end{array}$ & $\begin{array}{c}\text { After } \\
\text { TRA86 }\end{array}$ & Change & $\begin{array}{l}\text { Difference-in- } \\
\text { Difference }\end{array}$ \\
\hline High & $\begin{array}{c}595.7(31.7) \\
{[756]}\end{array}$ & $\begin{array}{c}801.7(35.2) \\
{[718]}\end{array}$ & $\begin{array}{c}206.0(47.4) \\
\{34.5 \%\}\end{array}$ & \\
\hline $\begin{array}{l}75^{\text {th }} \\
\text { Percentile }\end{array}$ & $\begin{array}{c}1033.3(15.0) \\
{[3799]}\end{array}$ & $\begin{array}{c}1154.5(15.3) \\
{[3613]}\end{array}$ & $\begin{array}{c}121.2(21.5) \\
\{11.7 \%\}\end{array}$ & $\begin{array}{c}84.8(51.5) \\
\{22.8 \%\}\end{array}$ \\
\hline $\begin{array}{l}90^{\text {th }} \\
\text { Percentile }\end{array}$ & $\begin{array}{c}876.4(15.2) \\
{[3765]}\end{array}$ & $\begin{array}{c}1005.2(16.0) \\
{[3579]}\end{array}$ & $\begin{array}{c}128.8(22.1) \\
\{14.7 \%\}\end{array}$ & $\begin{array}{c}77.4(52.5) \\
\{19.8 \%\}\end{array}$ \\
\hline
\end{tabular}

Each cell contains the mean for that group, along with standard errors in 0 , number of observations in [], and \% increase in \{\} . Means are unweighted. 
Table IV

Average Hourly Wage

\begin{tabular}{l||cccc} 
Group & $\begin{array}{l}\text { Before } \\
\text { TRA86 }\end{array}$ & $\begin{array}{c}\text { After } \\
\text { TRA86 }\end{array}$ & Change & $\begin{array}{c}\text { Relative } \\
\text { Change }\end{array}$ \\
\hline \hline \multirow{3}{*}{ High } & & & & \\
& $\$ 13.18$ & $(1.49)$ & $\$ 1.81$ & $(1.96)$ \\
$75^{\text {th }}$ & $(1.27)$ & & & \\
Percentile & $\$ 8.29$ & $\$ 9.47$ & $\$ 1.18$ & $\mathbf{0 . 6 3}$ \\
$90^{\text {th }}$ & $(0.12)$ & $(0.15)$ & $(0.19)$ & $\mathbf{( 1 . 9 7 )}$ \\
Percentile & $\$ 9.59$ & $\$ 10.89$ & $\$ 1.30$ & $\mathbf{0 . 5 1}$ \\
& $(0.17)$ & $(0.18)$ & $(0.25)$ & $\mathbf{( 1 . 9 7 )}$ \\
\hline \hline
\end{tabular}

Data are March CPS $1984-86$ and 1990-92. Average hourly wage is constructed by dividing wage and salary income by annual hours of work. It is deflated by the CPI to $1985 \$$. Standard errors are in parentheses. 
Table V

Probit Regression Results

Labor Force Participation

\begin{tabular}{|c|c|c|c|c|}
\hline \multirow{2}{*}{$\begin{array}{l}\text { Variables } \\
\text { High*Post86 }\end{array}$} & \multicolumn{2}{|c|}{ Control: $75^{\text {th }}$ Percentile } & \multicolumn{2}{|c|}{ Control: $90^{\text {th }}$ Percentile } \\
\hline & $\begin{array}{c}.070 \\
(.072)\end{array}$ & $\begin{array}{l}.100 \\
(.075)\end{array}$ & $\begin{array}{l}.110 \\
(.072)\end{array}$ & $\begin{array}{l}.120 \\
(.075)\end{array}$ \\
\hline Post86 & $\begin{array}{c}.014 \\
(.050)\end{array}$ & $\begin{array}{l}-.006 \\
(.052)\end{array}$ & $\begin{array}{r}.064 \\
(.05)\end{array}$ & $\begin{array}{c}.038 \\
(.051)\end{array}$ \\
\hline High & $\begin{array}{l}-.578 \\
(.050)\end{array}$ & $\begin{array}{l}-.746 \\
(.058)\end{array}$ & $\begin{array}{l}-.374 \\
(.050)\end{array}$ & $\begin{array}{c}-.411 \\
(.053)\end{array}$ \\
\hline Age & -- & $\begin{array}{c}.041 \\
(.012)\end{array}$ & -- & $\begin{array}{r}.025 \\
(.014)\end{array}$ \\
\hline $\mathrm{Age}^{2}$ & -- & $\begin{array}{c}-.001 \\
(.0001)\end{array}$ & -- & $\begin{array}{l}-.0006 \\
(.0001)\end{array}$ \\
\hline Education & -- & $\begin{array}{c}.005 \\
(.079)\end{array}$ & -- & $\begin{array}{l}-.335 \\
(.110)\end{array}$ \\
\hline Education $^{2}$ & -- & $\begin{array}{c}.018 \\
(.007)\end{array}$ & - & $\begin{array}{r}.044 \\
(.009)\end{array}$ \\
\hline Children $<6$ & -- & $\begin{array}{c}-.422 \\
(.030)\end{array}$ & -- & $\begin{array}{l}-.387 \\
(.030)\end{array}$ \\
\hline Black & -- & $\begin{array}{c}.373 \\
(.094)\end{array}$ & -- & $\begin{array}{c}.407 \\
(.121)\end{array}$ \\
\hline Husband Self-Employed & -- & $\begin{array}{c}.131 \\
(.042)\end{array}$ & - & $\begin{array}{c}.037 \\
(.033)\end{array}$ \\
\hline Log Likelihood & -5432 & -4935 & -5830 & -5349 \\
\hline Observations & 8886 & 8886 & 8817 & 8817 \\
\hline
\end{tabular}

Regressions in columns (1) and (3) include year dummies. Regressions in columns (2) and (4) include year dummies, state dummies, MSA and central city dummies. Data are March CPS 1984-86 and 1990-92. Standard errors are in parentheses. 
Table VIa

Predicted Participation Rate

Probit Estimates

\begin{tabular}{|c|c|c|c|c|}
\hline Group & $\begin{array}{l}\text { Before } \\
\text { TRA86 }\end{array}$ & $\begin{array}{c}\text { After } \\
\text { TRA86 }\end{array}$ & Change & $\begin{array}{c}\text { Differences-in- } \\
\text { Differences } \\
\text { Estimate }\end{array}$ \\
\hline
\end{tabular}

Control: $75^{\text {th }}$ Percentile

\begin{tabular}{l||c|c|c|c}
\hline \hline High & .460 & .497 & $\begin{array}{c}.037 \\
(8.1 \%)\end{array}$ & \\
\hline $75^{\text {th }}$ Percentile & .741 & .739 & $\begin{array}{c}-.002 \\
(-0.3 \%)\end{array}$ & $\begin{array}{c}.039 \\
(8.4 \%)\end{array}$ \\
\hline \hline
\end{tabular}

Control: $90^{\text {th }}$ Percentile

\begin{tabular}{l||c|c|c|c}
\hline \hline High & .480 & .542 & $\begin{array}{c}.062 \\
(13.1 \%)\end{array}$ & \\
\hline $90^{\text {th }}$ Percentile & .640 & .654 & $\begin{array}{c}.014 \\
(2.2 \%)\end{array}$ & $\begin{array}{c}.048 \\
(10.9 \%)\end{array}$ \\
\hline \hline
\end{tabular}

Predicted Participation is calculated as

$$
P(l f p)=\Phi(\bar{z} \hat{\alpha})
$$

where $z$ corresponds to the average characteristics in the sample.

Table VIb

Elasticity of Participation

High-Income Group

\begin{tabular}{l|c}
\hline \hline Control Group & Elasticity \\
\hline \hline $75^{\text {th }}$ Percentile & 0.4 \\
$90^{\text {th }}$ Percentile & 0.6 \\
\hline \hline
\end{tabular}


Table VII

Truncated Normal Regression Results

Annual Hours Conditional on Employment

\begin{tabular}{|c|c|c|c|c|}
\hline \multirow{2}{*}{$\begin{array}{l}\text { Variables } \\
\text { High*Post86 }\end{array}$} & \multicolumn{2}{|c|}{ Control: $75^{\text {th }}$ Percentile } & \multicolumn{2}{|c|}{ Control: $90^{\text {th }}$ Percentile } \\
\hline & $\begin{array}{l}142.80 \\
(71.12)\end{array}$ & $\begin{array}{l}115.32 \\
(63.21)\end{array}$ & $\begin{array}{r}95.17 \\
(82.55)\end{array}$ & $\begin{array}{c}65.80 \\
(71.89)\end{array}$ \\
\hline Post86 & $\begin{array}{c}64.49 \\
(24.15)\end{array}$ & $\begin{array}{c}16.56 \\
(36.11)\end{array}$ & $\begin{array}{c}48.95 \\
(49.37)\end{array}$ & $\begin{array}{c}30.62 \\
(43.29)\end{array}$ \\
\hline High & $\begin{array}{l}-276.91 \\
(52.66)\end{array}$ & $\begin{array}{c}-372.70 \\
(49.03)\end{array}$ & $\begin{array}{c}-205.73 \\
(61.27)\end{array}$ & $\begin{array}{r}-248.17 \\
(54.04)\end{array}$ \\
\hline Age & -- & $\begin{array}{r}53.63 \\
(8.88)\end{array}$ & -- & $\begin{array}{c}47.56 \\
(11.65)\end{array}$ \\
\hline $\mathrm{Age}^{2}$ & -- & $\begin{array}{c}-0.73 \\
(.11)\end{array}$ & -- & $\begin{array}{l}-0.69 \\
(.13)\end{array}$ \\
\hline Education & -- & $\begin{array}{r}-96.37 \\
(63.70)\end{array}$ & -- & $\begin{array}{r}-363.24 \\
(91.02)\end{array}$ \\
\hline Education $^{2}$ & -- & $\begin{array}{l}14.95 \\
(5.38)\end{array}$ & -- & $\begin{array}{l}34.95 \\
(7.38)\end{array}$ \\
\hline Children $<6$ & -- & $\begin{array}{l}-172.13 \\
(22.68)\end{array}$ & - & $\begin{array}{r}-198.89 \\
(29.69)\end{array}$ \\
\hline Black & -- & $\begin{array}{l}265.60 \\
(52.20)\end{array}$ & -- & $\begin{array}{l}311.55 \\
(77.20)\end{array}$ \\
\hline Husband Self-Employed & -- & $\begin{array}{c}-63.93 \\
(43.30)\end{array}$ & -- & $\begin{array}{c}-27.44 \\
(38.69)\end{array}$ \\
\hline$\sigma$ & $\begin{array}{l}808.12 \\
(12.32)\end{array}$ & $\begin{array}{c}729.17 \\
(8.15)\end{array}$ & $\begin{array}{l}895.23 \\
(12.30)\end{array}$ & $\begin{array}{l}798.35 \\
(10.17)\end{array}$ \\
\hline Log Likelihood & -48277 & -47739 & -43422 & -42926 \\
\hline Observations & -- & 6305 & -- & 5400 \\
\hline
\end{tabular}

Regressions in columns (1) and (3) include year dummies. Regressions in columns (2) and (4) include year dummies, state dummies, MSA and central city dummies as well as 9 occupation dummies. Data are March CPS 1984-86 and 1990-92. Standard errors are in parentheses. 
Table VIIIa

Predicted Total Hours of Work

Probit and Truncated Normal Estimates

\begin{tabular}{l|lccc}
\hline \hline Group & $\begin{array}{l}\text { Before } \\
\text { TRA86 }\end{array}$ & After & Change & $\begin{array}{c}\text { Differences-in - } \\
\text { Differences } \\
\text { Estimate }\end{array}$ \\
\hline \hline
\end{tabular}

Control: $75^{\text {th }}$ Percentile

\begin{tabular}{l||c|c|c|c}
\hline \hline High & 507.4 & 605.9 & $\begin{array}{c}98.5 \\
(19.4 \%)\end{array}$ & \\
\hline $75^{\text {th }}$ Percentile & 1070.1 & 1078.8 & $\begin{array}{c}8.7 \\
(1.0 \%)\end{array}$ & $\begin{array}{c}89.7 \\
(18.4 \%)\end{array}$ \\
\hline \hline
\end{tabular}

Control: $90^{\text {th }}$ Percentile

\begin{tabular}{l||c|c|c|c}
\hline \hline High & 525.4 & 637.3 & $\begin{array}{c}111.9 \\
(21.3 \%)\end{array}$ & \\
\hline $90^{\text {th }}$ Percentile & 835.7 & 872.5 & $\begin{array}{c}36.7 \\
(4.4 \%)\end{array}$ & $\begin{array}{c}75.1 \\
(16.9 \%)\end{array}$ \\
\hline \hline
\end{tabular}

Predicted hours are calculated as

$$
E(\hat{h})=\Phi\left(\overline{z^{\top}} \hat{\alpha}\right) \cdot(\bar{x} \hat{\beta}+\hat{\sigma} \lambda(\bar{x} \hat{\beta}))
$$

where ${ }^{\wedge}$ are probit coefficients; $\beta^{\wedge}$ and $\sigma^{\wedge}$ are truncated normal coefficients.

Table VIIIb

Elasticity of Total Hours of Work

High-Income Group

\begin{tabular}{l|c}
\hline \hline Control Group & Elasticity \\
\hline \hline $75^{\text {th }}$ Percentile & 0.8 \\
& \\
$90^{\text {th }}$ Percentile & 1.0 \\
\hline \hline
\end{tabular}


Table IX

Tobit Regression Results

Total Hours of Work

\begin{tabular}{|c|c|c|c|c|}
\hline \multirow{2}{*}{$\begin{array}{l}\text { Variables } \\
\text { High*Post86 }\end{array}$} & \multicolumn{2}{|c|}{ Control: $75^{\text {th }}$ Percentile } & \multicolumn{2}{|c|}{ Control: $90^{\text {th }}$ Percentile } \\
\hline & $\begin{array}{c}172.74 \\
(78.42)\end{array}$ & $\begin{array}{c}189.40 \\
(72.20)\end{array}$ & $\begin{array}{r}172.18 \\
(87.16)\end{array}$ & $\begin{array}{c}167.24 \\
(80.00)\end{array}$ \\
\hline Post86 & $\begin{array}{c}42.76 \\
(50.27)\end{array}$ & $\begin{array}{c}13.11 \\
(46.11)\end{array}$ & $\begin{array}{c}90.32 \\
(56.56)\end{array}$ & $\begin{array}{c}51.65 \\
(51.86)\end{array}$ \\
\hline High & $\begin{array}{l}-726.12 \\
(55.65)\end{array}$ & $\begin{array}{c}-842.34 \\
(55.40)\end{array}$ & $\begin{array}{l}-510.99 \\
(61.83)\end{array}$ & $\begin{array}{l}-513.59 \\
(58.01)\end{array}$ \\
\hline Age & -- & $\begin{array}{r}87.20 \\
(11.01)\end{array}$ & -- & $\begin{array}{c}63.75 \\
(13.79)\end{array}$ \\
\hline $\mathrm{Age}^{2}$ & -- & $\begin{array}{l}-1.360 \\
(.128)\end{array}$ & -- & $\begin{array}{r}-1.15 \\
(.15)\end{array}$ \\
\hline Education & -- & $\begin{array}{r}50.00 \\
(74.06)\end{array}$ & -- & $\begin{array}{c}-438.30 \\
(110.21)\end{array}$ \\
\hline Education $^{2}$ & -- & $\begin{array}{l}15.59 \\
(6.31)\end{array}$ & -- & $\begin{array}{l}55.56 \\
(8.97)\end{array}$ \\
\hline Children $<6$ & -- & $\begin{array}{l}-407.21 \\
(26.67)\end{array}$ & -- & $\begin{array}{c}-445.7 \\
(31.73)\end{array}$ \\
\hline Black & - & $\begin{array}{l}421.36 \\
(72.43)\end{array}$ & -- & $\begin{array}{c}558.44 \\
(106.70)\end{array}$ \\
\hline Husband Self Employed & -- & $\begin{array}{c}66.46 \\
(39.71)\end{array}$ & -- & $\begin{array}{c}-36.80 \\
(44.75)\end{array}$ \\
\hline$\sigma$ & $\begin{array}{r}1269.0 \\
(12.55)\end{array}$ & $\begin{array}{l}1152.6 \\
(11.33)\end{array}$ & $\begin{array}{c}1401.19 \\
(14.85)\end{array}$ & $\begin{array}{c}1269.51 \\
(13.36)\end{array}$ \\
\hline Log Likelihood & -54280 & -53532 & -49635 & -48922 \\
\hline Observations & -- & 8886 & -- & 8817 \\
\hline
\end{tabular}

Regressions in columns (1) and (3) include year dummies. Regressions in columns (2) and (4) include year dummies, state dummies, SMSA and central city dummies. Data are March CPS 1984-86 and 1990-92. Standard errors are in parentheses. 
Table Xa

Predicted Total Hours of Work

Tobit Estimates

\begin{tabular}{c||lccc}
\hline \hline Group & $\begin{array}{l}\text { Before } \\
\text { TRA86 }\end{array}$ & $\begin{array}{c}\text { After } \\
\text { TRA86 }\end{array}$ & Change & $\begin{array}{c}\text { Differences-in } \\
\text { Differences } \\
\text { Estimate }\end{array}$ \\
\hline \hline
\end{tabular}

Control: $75^{\text {th }}$ Percentile

\begin{tabular}{c||c|c|c|c}
\hline \hline High & 484.1 & 595.8 & $\begin{array}{c}101.7 \\
(23.1 \%)\end{array}$ & \\
\hline $75^{\text {th }}$ Percentile & 1035.8 & 1046.0 & $\begin{array}{c}10.3 \\
(1.0 \%)\end{array}$ & $\begin{array}{c}91.4 \\
(22.1 \%)\end{array}$ \\
\hline \hline
\end{tabular}

Control: $90^{\text {th }}$ Percentile

\begin{tabular}{c||c|c|c|c}
\hline \hline High & 537.6 & 659.5 & $\begin{array}{c}121.9 \\
(22.7 \%)\end{array}$ & \\
\hline $90^{\text {th }}$ Percentile & 850.4 & 885.3 & $\begin{array}{c}34.9 \\
(4.1 \%)\end{array}$ & $\begin{array}{c}87.1 \\
(18.6 \%)\end{array}$ \\
\hline \hline
\end{tabular}

Predicted hours are calculated as

$$
E(\hat{h})=\Phi(\bar{x} \hat{\gamma}) \bar{x} \hat{\gamma}+\hat{\sigma} \lambda(\bar{x} \hat{\gamma})
$$

Table Xb

Elasticity of Total Hours of Work

High-Income Group

\begin{tabular}{l|c}
\hline \hline Control Group & Elasticity \\
\hline \hline $75^{\text {th }}$ Percentile & 1.0 \\
& \\
$90^{\text {th }}$ Percentile & 1.1 \\
\hline \hline
\end{tabular}


Table XI

Regression Results-Education Interaction

\begin{tabular}{|c|c|c|c|}
\hline Variables & Probit & $\begin{array}{c}\text { Truncated } \\
\text { Normal }\end{array}$ & Tobit \\
\hline \multicolumn{4}{|l|}{ Control: $7^{\text {th }}$ Percentile } \\
\hline High*Post86 & $\begin{array}{c}.05 \\
(.08)\end{array}$ & $\begin{array}{l}118.87 \\
(64.54)\end{array}$ & $\begin{array}{l}164.73 \\
(74.09)\end{array}$ \\
\hline Post86 & $\begin{array}{l}-.38 \\
(.16)\end{array}$ & $\begin{array}{c}45.91 \\
(113.8)\end{array}$ & $\begin{array}{r}-170.20 \\
(143.47)\end{array}$ \\
\hline High & $\begin{array}{l}-.72 \\
(.06)\end{array}$ & $\begin{array}{l}-374.50 \\
(49.49)\end{array}$ & $\begin{array}{l}-836.93 \\
(56.25)\end{array}$ \\
\hline Education & $\begin{array}{l}-.02 \\
(.08)\end{array}$ & $\begin{array}{l}-94.89 \\
(63.95)\end{array}$ & $\begin{array}{l}13.12 \\
(99.8)\end{array}$ \\
\hline Education*Post 86 & $\begin{array}{l}.07 \\
(.03)\end{array}$ & $\begin{array}{c}-4.99 \\
(18.35)\end{array}$ & $\begin{array}{c}32.25 \\
(23.62)\end{array}$ \\
\hline Log Likelihood & -4932 & -47739 & -53488 \\
\hline \multicolumn{4}{|l|}{ Control: $90^{\text {th }}$ Percentile } \\
\hline High*Post86 & $\begin{array}{c}.12 \\
(.07)\end{array}$ & $\begin{array}{c}71.87 \\
(72.16)\end{array}$ & $\begin{array}{l}179.64 \\
(80.44)\end{array}$ \\
\hline Post86 & $\begin{array}{c}.17 \\
(.17)\end{array}$ & $\begin{array}{c}131.35 \\
(143.5)\end{array}$ & $\begin{array}{c}311.06 \\
(169.94)\end{array}$ \\
\hline High & $\begin{array}{l}-.41 \\
(.05)\end{array}$ & $\begin{array}{l}-255.74 \\
(53.61)\end{array}$ & $\begin{array}{c}-530.98 \\
(58.40)\end{array}$ \\
\hline Education & $\begin{array}{l}-.33 \\
(.11)\end{array}$ & $\begin{array}{l}-363.74 \\
(91.02)\end{array}$ & $\begin{array}{c}-499.24 \\
(130.5)\end{array}$ \\
\hline Education*Post86 & $\begin{array}{l}-.02 \\
(.02)\end{array}$ & $\begin{array}{l}-16.15 \\
(21.82)\end{array}$ & $\begin{array}{c}-42.63 \\
(26.40)\end{array}$ \\
\hline Log Likelihood & -5349 & -42926 & -48911 \\
\hline \multicolumn{4}{|c|}{$\begin{array}{l}\text { Other covariates include age, age }{ }^{2} \text {, education, education }{ }^{2} \text {, children under } 6 \text {, state and } \\
\text { residence dummies. A set of } 9 \text { occupation dummies is included in the truncated normal } \\
\text { regression. Data are March CPS } 1984-86 \text { and } 1990-92 \text {. Standard errors are in parentheses. }\end{array}$} \\
\hline
\end{tabular}


Table XII

Regression Results

Married Women, CPS 1983 \& 1985

\begin{tabular}{|c|c|c|c|c|c|c|c|}
\hline Variables & \multicolumn{2}{|c|}{ Probit } & \multicolumn{3}{|c|}{$\begin{array}{c}\text { Truncated } \\
\text { Normal }\end{array}$} & \multicolumn{2}{|c|}{ Tobit } \\
\hline \multicolumn{8}{|l|}{$\begin{array}{l}\text { Control: } 7^{\text {th }} \\
\text { Percentile }\end{array}$} \\
\hline High*T85 & $\begin{array}{c}.03 \\
(.12)\end{array}$ & $\begin{array}{l}.05 \\
(.13)\end{array}$ & $\begin{array}{r}-29.59 \\
(137.9)\end{array}$ & $\begin{array}{c}-3.61 \\
(126.9)\end{array}$ & $\begin{array}{r}52.39 \\
(122.7)\end{array}$ & $\begin{array}{c}45.09 \\
(139.2)\end{array}$ & $\begin{array}{c}79.68 \\
(127.4)\end{array}$ \\
\hline $\mathrm{T} 85$ & $\begin{array}{c}.13 \\
(.04)\end{array}$ & $\begin{array}{c}.07 \\
(.058)\end{array}$ & $\begin{array}{c}49.62 \\
(45.28)\end{array}$ & $\begin{array}{l}39.71 \\
(43.7)\end{array}$ & $\begin{array}{l}47.11 \\
(42.5)\end{array}$ & $\begin{array}{c}144.24 \\
(53.9)\end{array}$ & $\begin{array}{l}69.84 \\
(51.5)\end{array}$ \\
\hline High & $\begin{array}{l}-.58 \\
(.09)\end{array}$ & $\begin{array}{l}-.68 \\
(.10)\end{array}$ & $\begin{array}{l}-283.03 \\
(100.3)\end{array}$ & $\begin{array}{c}-314.68 \\
(95.2)\end{array}$ & $\begin{array}{c}-352.84 \\
(92.2)\end{array}$ & $\begin{array}{c}-740.10 \\
(99)\end{array}$ & $\begin{array}{c}-779.43 \\
(98.3)\end{array}$ \\
\hline $\begin{array}{l}\text { Log } \\
\text { Likelihood }\end{array}$ & -1903 & -1678 & -15746 & -15746 & -15573 & -17794 & -17521 \\
\hline Observations & 3016 & 3016 & 1966 & 1966 & 1966 & 3016 & 3016 \\
\hline \multicolumn{8}{|l|}{$\begin{array}{l}\text { Control: } 90^{\text {th }} \\
\text { Percentile }\end{array}$} \\
\hline High*T85 & $\begin{array}{c}.07 \\
(.12)\end{array}$ & $\begin{array}{c}.04 \\
(.13)\end{array}$ & $\begin{array}{c}-8.92 \\
(159.1)\end{array}$ & $\begin{array}{c}15.53 \\
(144.3)\end{array}$ & $\begin{array}{c}90.25 \\
(137.2)\end{array}$ & $\begin{array}{c}90.34 \\
(153.4)\end{array}$ & $\begin{array}{c}69.82 \\
(142.3)\end{array}$ \\
\hline T85 & $\begin{array}{c}.09 \\
(.05)\end{array}$ & $\begin{array}{l}.11 \\
(.05)\end{array}$ & $\begin{array}{c}30.64 \\
(55.73)\end{array}$ & $\begin{array}{c}33.83 \\
(52.79)\end{array}$ & $\begin{array}{l}27.57 \\
(50.4)\end{array}$ & $\begin{array}{l}110.37 \\
(60.5)\end{array}$ & $\begin{array}{l}113.46 \\
(57.9)\end{array}$ \\
\hline High & $\begin{array}{l}-.37 \\
(.09)\end{array}$ & $\begin{array}{l}-.41 \\
(.09)\end{array}$ & $\begin{array}{l}-245.25 \\
(115.7)\end{array}$ & $\begin{array}{c}-239.66 \\
(105.9)\end{array}$ & $\begin{array}{l}-264.86 \\
(100.6)\end{array}$ & $\begin{array}{c}-573.03 \\
(109.0)\end{array}$ & $\begin{array}{c}-578.56 \\
(103.7)\end{array}$ \\
\hline $\log$ & & & & & & & \\
\hline Likelihood & -2018 & -1844 & -14048 & -13929 & -13876 & -16164 & -15932 \\
\hline Observations & 2998 & 2998 & 1748 & 1748 & 1748 & 2998 & 2998 \\
\hline \multicolumn{8}{|c|}{$\begin{array}{l}\text { T85 =1 for } 1985 \\
\quad=0 \text { for } 1983 \\
\text { Specification in columns (1), (3) and (6) include no other covariates. Columns (2), (5) and (7) } \\
\text { include year age, age }{ }^{2} \text {, education, education }{ }^{2} \text {, children under } 6 \text {, year, state, MSA and central city } \\
\text { dummies. Column (4) excludes occupation controls. For brevity, I report only relevant } \\
\text { coefficients. Data are March CPS } 1984 \text { and 1986. Standard errors are in parentheses. }\end{array}$} \\
\hline
\end{tabular}


marginal

tax rate

$\mid$

Income Tax Schedule, 1985

Figure I

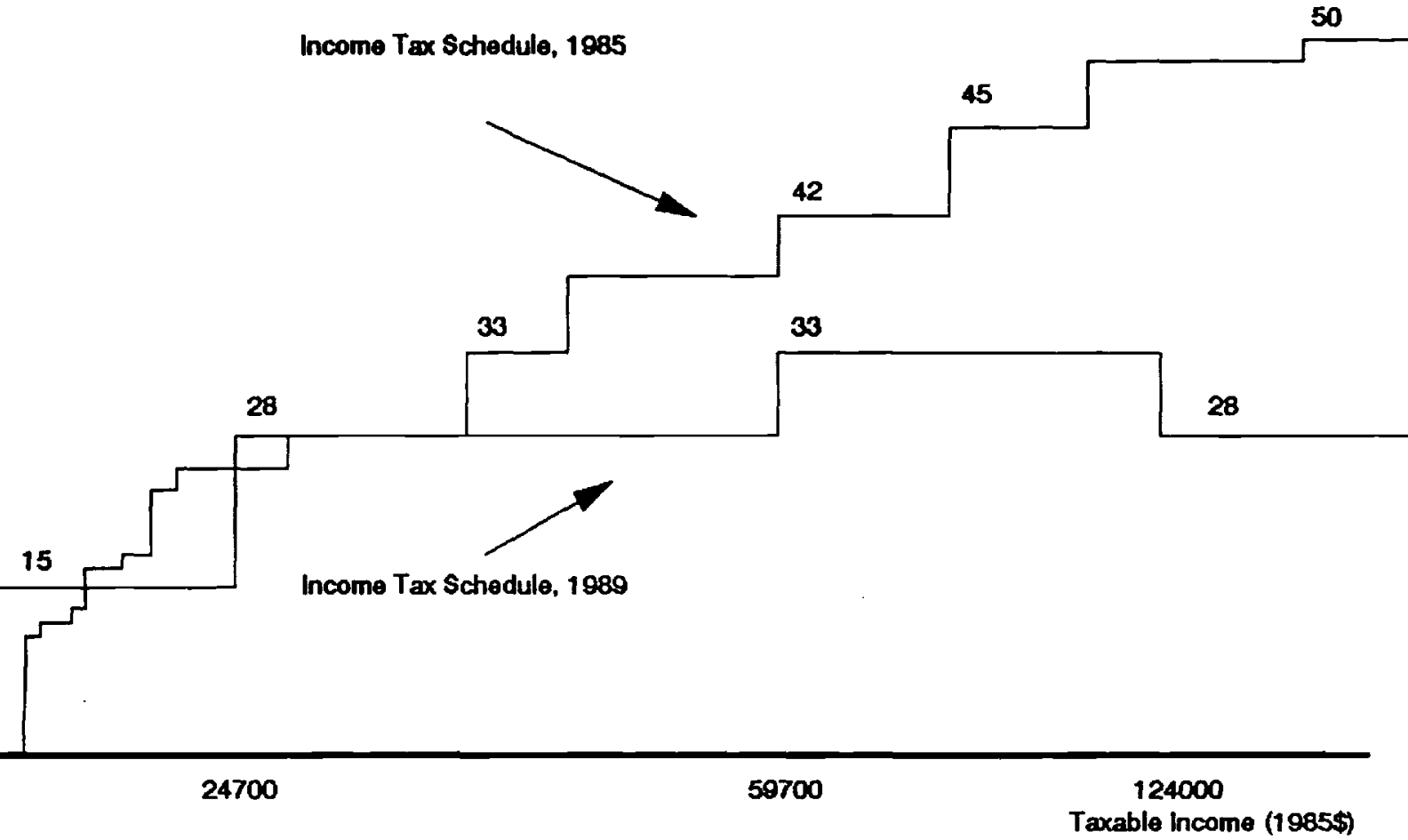




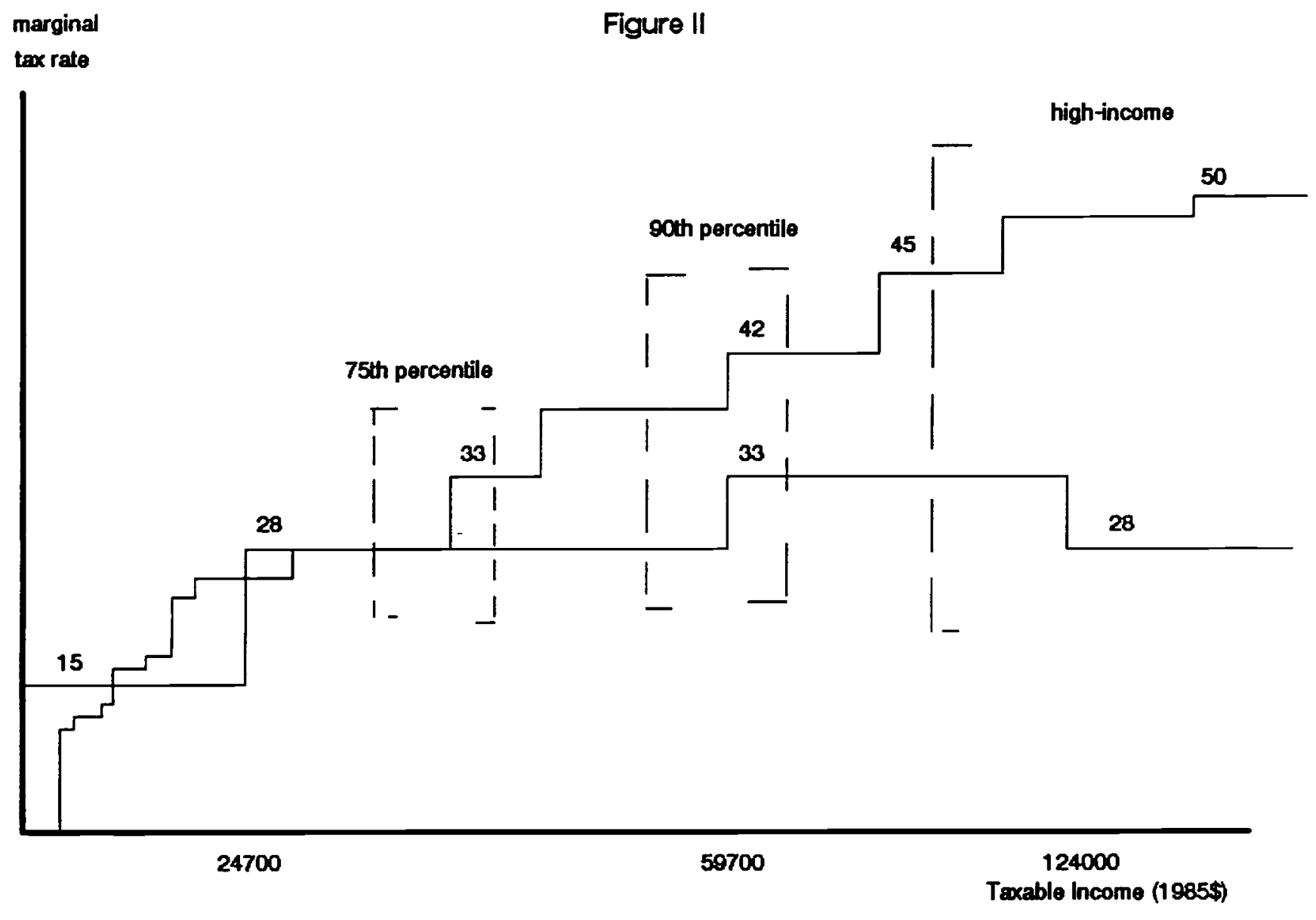

